PONTIFÍCIA UNIVERSIDADE CATÓLICA DO RIO DE JANEIRO

\title{
Aplicação da Técnica de Manufatura Enxuta na Melhoria de Processos Internos do Setor Financeiro de uma Empresa de Varejo
}

Autor: Gabriel de Chermont Feitoza

Orientador: Martim Francisco de Oliveira e Silva

Trabalho de Conclusão de Curso

Centro de CIÊnCIAS SOCIAIS - CCS

DEPARTAMENTO DE AdMINISTRAÇÃO

Graduação em Administração de Empresas 
Gabriel de Chermont Feitoza

\section{Aplicação da Técnica de Manufatura Enxuta Na Melhoria de Processos Internos do Setor Financeiro de uma Empresa de Varejo}

Trabalho de Conclusão de Curso

Trabalho de Conclusão de Curso, apresentado ao programa de graduação em Administração da PUC-Rio como requisito parcial para a obtenção do título de graduação em Administração.

Orientador(a): Martim Francisco de Oliveira e Silva 
"Você não ganha para trabalhar, você ganha para resolver problemas, criar soluções e encantar clientes. O trabalho é o meio, não o fim."

(Ricardo Amorim) 


\section{Agradecimentos}

A minha mãe, Angela Chermont, ao meu pai lazaldir Feitoza e a minha família pelo suporte e incentivo ao longo da minha graduação.

Ao casal Rafaela e Christiano Chermont, que me deram o privilégio de ser padrinho de casamento do casal e padrinho de batizado do meu sobrinho Bernardo.

Ao casal Marisa e Carlos Lucena pelo suporte e incentivo que me deram para que eu continuasse a trilhar minhas conquistas no curso de graduação.

Ao meu professor da disciplina de Projeto de Monografia, Edmundo Eutrópio, que me auxiliou na elaboração da primeira parte desse artigo.

Ao meu orientador da monografia, Martim Francisco de Oliveira e Silva, que me conduziu na elaboração dos capítulos principais do artigo.

Ao professor Marcos Lopez Rego, pelos feedbacks comentados durante a apresentação final na banca de avaliação.

À professora Sylvia Therezinha de Almeida Moraes, pelos comentários durante a apresentação final na banca de avaliação.

À professora Renata Geórgia Motta Kurtz, pelos conselhos compartilhados durante o primeiro semestre quanto ao processo de adaptação ao curso.

À coordenadora financeira da empresa em estudo, Ana Carolina Aragão, que contribuiu com ideias e sugestões quanto os pontos do setor que deveriam ser o foco do trabalho.

Ao CEO da empresa, Filipe Barbosa, por toda atenção e apoio que me dá na empresa desde a época em que eu era estagiário.

Aos colaboradores das áreas de Tesouraria e Fiscal, pela parceria durante 0 semestre de pesquisas, estudos e obtenção de informações para esse artigo.

Ao meu colega de trabalho Leonardo Batista, pela disponibilidade de ceder informações sobre as tarefas e demandas da área Fiscal da empresa.

Aos meus colegas de trabalho Gabriel Fernandes e Mariana Coutinho, pela disponibilidade de ceder informações sobre os dados e números financeiros da empresa. 


\section{Resumo}

De Chermont Feitoza, Gabriel. Aplicação da Técnica de Manufatura Enxuta na Melhoria de Processos Internos do Setor Financeiro de uma Empresa de Varejo. Rio de Janeiro, 2021. Número de páginas: 56. Trabalho de Conclusão de Curso - Departamento de Administração. Pontifícia Universidade Católica do Rio de Janeiro.

O presente artigo tecnológico tem como objetivo principal analisar o setor Financeiro de uma empresa de varejo em artefatos de couro, com ênfase nas áreas de Tesouraria e Fiscal, no que tange ao mapeamento de processos e à análise de variáveis de desempenho com base na conceituação teórica sobre as técnicas de Manufatura Enxuta. A partir da verificação das limitações e dos gargalos nos processos que envolvem o pagamento de pedidos com notas de serviços, o artigo pretende elencar as principais melhorias e oportunidades que envolvem a execução dessa atividade operacional das duas áreas a fim de redesenhar um processo otimizado para todos os agentes envolvidos.

Palavras- chave: Contas a Pagar, Tesouraria, Financeiro, Gargalos, Processos e Manufatura Enxuta.

\section{Abstract}

De Chermont Feitoza, Gabriel. Application of Lean Manufacturing Technique in the Improvement of Internal Processes of the Financial Sector of a Retail Company. Rio de Janeiro, 2021. Number of pages: 56 . Course Completion Work - Administration Department. Pontifical Catholic University of Rio de Janeiro.

The main objective of this technological article is to analyze the Financial sector of a retail company in leather artifacts, with emphasis in the areas of Treasury and Tributary, with regard to process mapping and analysis of performance variables based on the theoretical conceptualization of Lean Manufacturing techniques. From the verification of limitations and bottlenecks in processes involving the payment of orders with service notes, the article intends to list the main improvements and opportunities that involve the execution of this operational activity of the two areas in order to redesign an optimized process for all agents involved.

Keywords: Accounts Payable, Treasury, Financial, Bottlenecks, Processes and Lean Manufacturing. 


\section{Sumário}

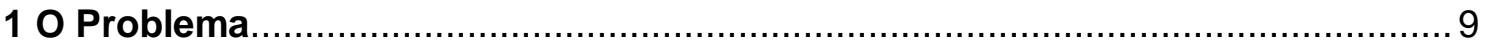

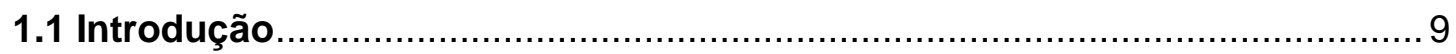

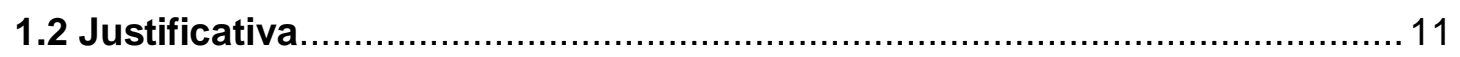

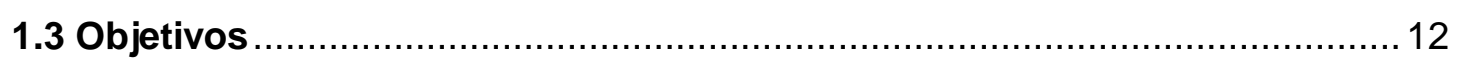

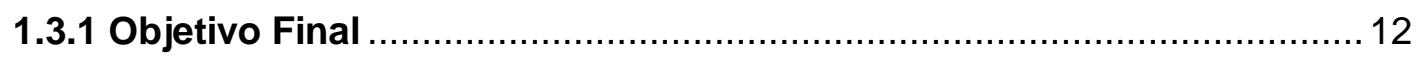

1.3.2 Objetivos Intermediários ........................................................ 12

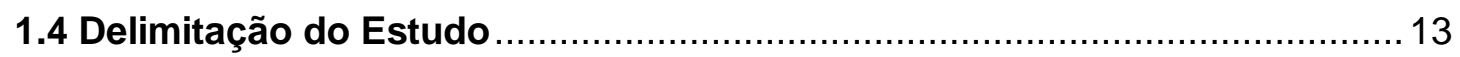

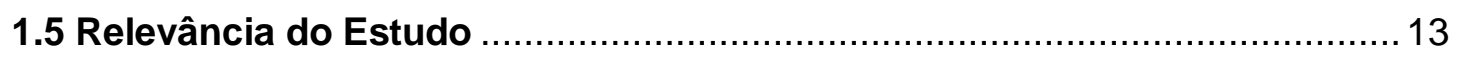

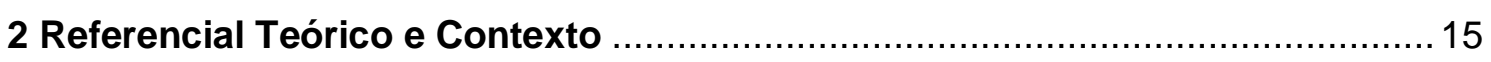

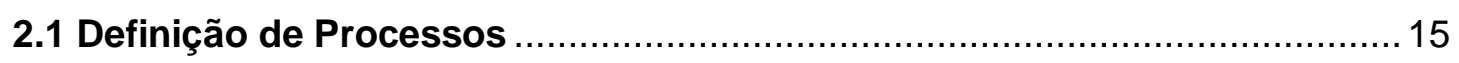

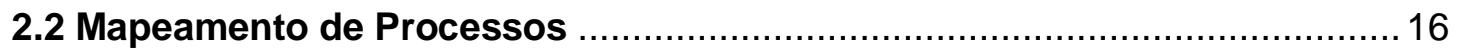

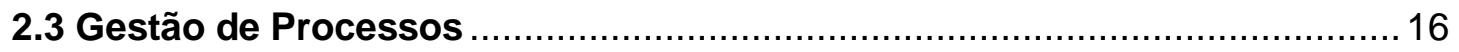

2.3.1 BPM (Business Process Management) ....................................... 17

2.3.2 BPMN (Business Process Model and Notation) ................................. 19

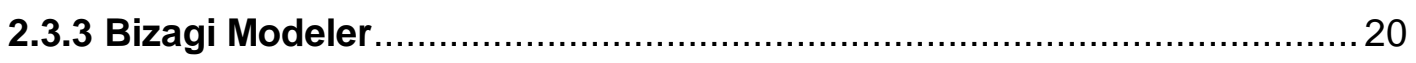

2.4 Introdução à Teoria da Manufatura Enxuta ............................................. 20

2.5 Características da Manufatura Enxuta .......................................................... 22

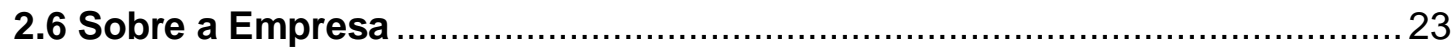

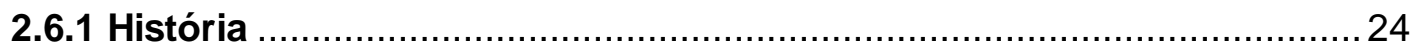

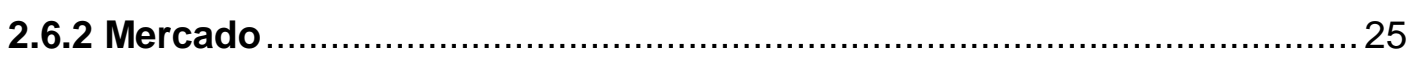

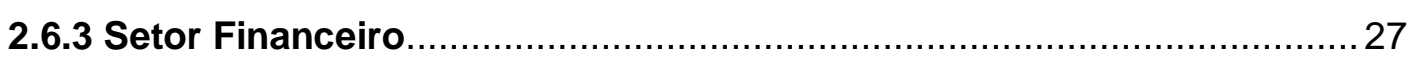

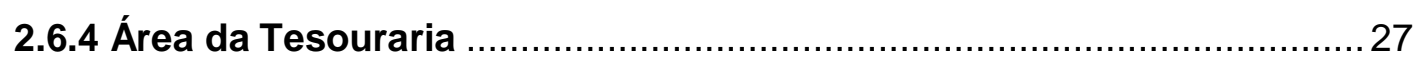

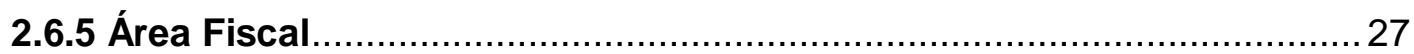

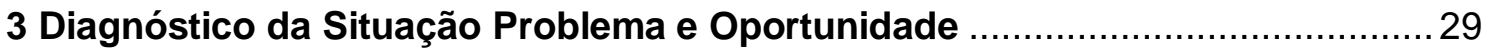

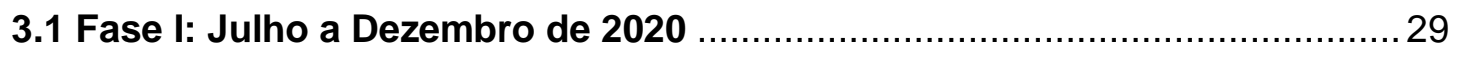

3.1.1 Apresentação do Fluxograma do Processo .......................................... 29

3.1.2 Diagnóstico do Fluxograma do Processo ............................................. 31

3.1.3 Oportunidade Diante do Fluxograma do Processo ............................. 32

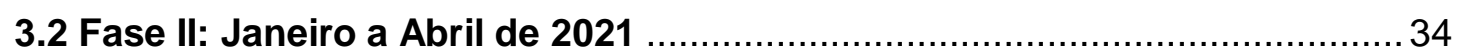

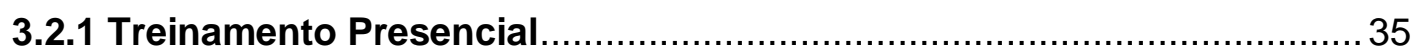

3.2.2 Apresentação do Fluxograma do Processo .......................................... 37

3.2.3 Diagnóstico do Fluxograma do Processo ......................................... 40

3.2.4 Oportunidade Diante do Fluxograma do Processo .............................. 44

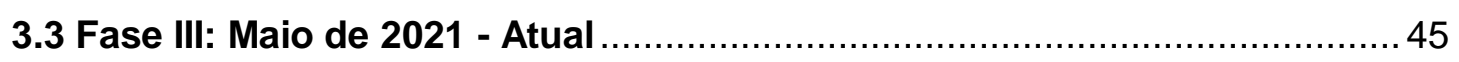

4 Análise da Situação e Proposta de Solução ................................................... 46

4.1 Utilização da Ferramenta do Bizagi Modeler ............................................... 46 
4.2 Utilização das Técnicas da Manufatura Enxuta 46

4.3 Apresentação do Fluxograma do Processo 48

4.4 Diagnóstico do Fluxograma do Processo …............................................. 50

5 Conclusões e Contribuições do Estudo.......................................................... 51

6 Referências Bibliográficas .54 


\section{Lista de Figuras}

Figura 1: Fluxograma do Mapeamento do Primeiro Processo ................................... 30

Figura 2: Fluxograma do Mapeamento do Processo Transitório .................................. 39

Figura 3: Exemplo de E-mail Solicitando Revisão de Lançamento............................. 43

Figura 4: Fluxograma do Mapeamento do Processo Final ...................................... 49

\section{Lista de Gráficos}

Gráfico 1: Distribuição Regional das Lojas pelo Brasil 25

\section{Lista de Tabelas}

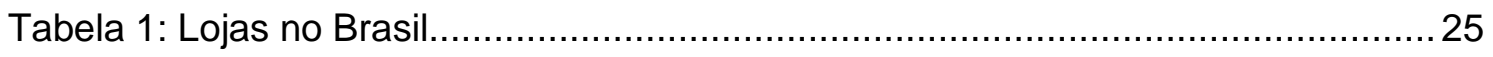

Tabela 2: Faturamento Percentual de Vendas ..................................................... 26

Tabela 3: Dados do Fluxograma do Primeiro Processo ........................................... 30

Tabela 4: Dados do Fluxograma do Processo Projetado ........................................... 34

Tabela 5: Dados Gerais do Treinamento Presencial ................................................. 36

Tabela 6: Dados Detalhados do Treinamento Presencial............................................... 36

Tabela 7: Informações do Fluxograma do Processo Transitório................................... 38

Tabela 8: Dados do Fluxograma do Processo Transitório: Projetado x Real................ 38

Tabela 9: Informações do Fluxograma do Processo Final......................................... 48

Tabela 10: Dados do Fluxograma do Processo Final: Projetado x Real ...................... 49 


\section{Problema}

\subsection{Introdução}

De acordo com Lucinda (2010), a qualidade dos produtos e dos serviços de uma empresa está diretamente associada com a qualidade dos processos internos e operacionais, de modo que seja possível atender às necessidades de seus clientes tanto internos quanto externos quando esse alinhamento estiver coerente. Para Keller e Kotler (2019), o valor que é entregue ao cliente final é a diferença de todo o valor agregado durante um processo do produto ou serviço e de todo o custo envolvido durante sua execução. Nesses paralelos, essa entrega final de valor também se aplica à execução de processos internos em uma empresa, mesmo que o foco processual nesse ambiente seja a prestação de um comando ou pedido interno entre colaboradores.

Diante disso, reforça-se o quão imprescindível é conhecer os próprios processos internos e operacionais em uma organização para que o produto ou o serviço final ofertado ao cliente esteja ao seu agrado e ao seu esperado. Nessa analogia, sendo o cliente ou o consumidor final de um produto ou serviço ofertado pela empresa ou um solicitante de prestação de um serviço a ser executado internamente em um departamento empresarial, por exemplo.

Para que isso seja atingido na realidade empresarial administrativa, existem no mercado inúmeras ferramentas oficiais de modelagens de processos que permitem a montagem e a visualização de fluxos contínuos de relacionamentos entre vários agentes envolvidos em uma mesma operação. Como bem destacado por Araújo (2011), a modelagem de processos é uma representação gráfica a partir de um conjunto de símbolos em um fluxograma que possibilita a análise de informações a respeito de atividades, setores e profissionais envolvidos na execução de uma tarefa empresarial.

Por sua vez, uma ferramenta de mapeamento de processos permite que sejam analisadas variáveis de desempenho que sustentarão os argumentos apresentados dos pontos fracos da cadeia de relacionamento que inibem a máxima otimização processual. E quanto à teoria acadêmica que deu suporte ao assunto mencionado, o sistema da Manufatura Enxuta, que tem foco principal na diminuição do lead time e na eliminação máxima dos desperdícios existentes nos processos (JONES e WOMACK, 1998), foi o principal recurso teórico para validação do alcance da máxima produtividade e efetividade das operações do processo. Afinal, a Manufatura Enxuta, a partir do uso de variáveis de desempenho classificadas como fontes de desperdícios, tem como objetivo principal para o administrador o alinhamento da sequência maximizadora do trabalho a 
fim de agregar valores com base nas variáveis de desempenho que permitem a diminuição de desperdícios percebidos (JONES e WOMACK, 1998).

Para esse trabalho no modelo de um artigo tecnológico, foi considerado como estudo de caso uma empresa de varejo do segmento de artefatos de couro e artigos de viagem de escala nacional, com sede administrativa no Rio de Janeiro. Diante de percepções mais claras sobre quais os fatores limitadores na rede de relacionamento do setor Financeiro da empresa, o redesenho de modelagens de processos, já considerando a eliminação das etapas impeditivas, a redução de tempo de execução e a agregação de oportunidades de melhorias, permitiu uma melhor identificação de como a empresa de varejo desse estudo poderá tomar futuras decisões de negócios e trabalhar sua rede de relacionamento entre a área de Tesouraria e o Fiscal de forma otimizada para todos os envolvidos.

No Brasil, por exemplo, existe um programa criado pelo Governo Federal chamado "Brasil Mais", que se trata de uma iniciativa visando o aumento da produtividade e da competitividade de empresas brasileiras, com a promoção de melhorias rápidas, de baixo custo e alto impacto. Nisso, segundo informações do site oficial do Ministério da Economia, o programa oferece soluções para melhorar a gestão, inovar processos e reduzir desperdícios. Em convergência com a proposta desse artigo, o Brasil + é um programa baseado no aumento da produtividade garantida pelas capacidades gerenciais sustentadas pela transformação digital e Economia 4.0.

Nessa visão, a gestão de desempenho do programa incentiva as empresas no desenvolvimento da cultura da melhoria contínua para o alcance dos objetivos, metas e resultados tangíveis. O programa trabalha nessa área com as dimensões de Lean Manufacturing, indicadores, metas, planejamento de longo prazo, estratégia de negócios, pensamento crítico, priorização e visão de oportunidades. Já no que tange à gestão de capital humano, o programa busca melhorar os resultados e processos internos da empresa de acordo com as habilidades e competências dos colaboradores por meio da disseminação interna do conhecimento para gerar liderança, performance, promoção e reconhecimento pelo trabalho. Essas duas questões levantadas das gestões de desempenho e de capital humano convergiram com o propósito desse artigo ao incentivar que a própria empresa visualize seus mecanismos internos e incentive mudanças inéditas em busca da otimização de processos que atualmente geram desgastes, retrabalho e esforços dobrados no departamento Financeiro.

Por meio dessas questões levantadas acerca da necessidade de desenhar modelagens inéditas dos processos visando a identificação de gargalos, a eliminação 
de desperdícios e a otimização da sequência de trabalho para futuras tomadas de decisões, o presente trabalho utilizou como base uma das ferramentas mais avançadas atualmente no quesito dessas análises processuais. Para esse artigo em questão, tratou-se do software Bizagi Modeler, que se baseia no padrão BPMN (Business Process Model and Notation) explicado no capítulo 2, como a ferramenta utilizada para a realização, desenho e documentação dos modelos de processos que envolvem as áreas de Tesouraria e Fiscal do setor Financeiro de uma empresa do segmento de varejo de artefatos de couro e artigos de viagem.

Assim, foram empregadas técnicas de análise de melhoria de processos internos com base nas observações e experiências adquiridas na área de Tesouraria da empresa pelo autor do artigo, em que se tornou possível identificar, após a montagem do fluxograma principal, quais eram os principais gargalos e limitações que existiam no eixo comunicacional entre a Tesouraria e o Fiscal no que tange aos pagamentos que contêm pedidos acompanhados de notas fiscais.

Com ênfase assim nas áreas de Tesouraria e Fiscal, que cuidam do trâmite dos pagamentos de pedidos com notas fiscais, a fim de responder à seguinte pergunta: Quais as principais oportunidades de melhorias nos processos internos utilizados pelo setor Financeiro da empresa em estudo no que tange à comunicação e à execução dessas atividades entre as áreas de Tesouraria e Fiscal?

\subsection{Justificativa}

Diante de observações, análises e vivências práticas, foi possível identificar que os anteriores processos manuais e operacionais ensinados e direcionados no setor Financeiro da companhia: possuem limitações e gargalos e são robustos e inflexíveis em certos aspectos. Ou seja, podem ser modificados e otimizados. Ao longo do artigo, inúmeros desses obstáculos processuais com participação da área de Tesouraria foram mencionados e detalhados a fim de que se possa compreender qual o conteúdo observado que motivou o autor a estudar e apurar esse assunto.

Posto isso, para a realização desse trabalho, foram utilizados os recursos ligados a mapeamento de processos através do software Bizagi Modeler e análise de variáveis de desempenho e técnicas da Manufatura Enxuta no que tange às fontes de desperdícios e identificação dos gargalos.

Em consoante com essa questão, o propósito do artigo também está associado com a possibilidade de que o material analisado e captado nessa pesquisa seja utilizado como um documento de consultoria à empresa estudada, a fim de que os profissionais 
superiores tenham acesso à esse conteúdo como forma de feedback sobre as atividades operacionais que englobam o setor Financeiro. Com isso, a extração e a apuração de resultados por meio da coleta de observações permitem que a empresa utilize esse material a fim de analisar, verificar, testar e concluir o que de fato é pertinente como forma de melhoria e aumento de produtividade e da eficiência dos colaboradores que integram o setor Financeiro. Inclusive, em convergência com as propostas práticas alinhadas no programa Brasil Mais do Ministério da Economia principalmente no que tange à valorização do capital humano de ambas as áreas.

Além de que esse estudo detalhado, recente e atual também é uma grande oportunidade para que a empresa e os demais funcionários pertencentes de ambas as áreas tenham dados e inferências inéditas e suficientes para compreender a situação real do setor Financeiro da companhia em questão, bem como se preparar para futuras tomadas de decisões caso de fato seja identificado que os problemas apontados no estudo possam ser aprimorados e modificados.

\subsection{Objetivos}

Nessa parte do artigo, são apresentados o objetivo final do mesmo e os objetivos intermediários que auxiliaram o autor desse documento a testar suas hipóteses para que se chegue à uma conclusão geral e mais verídica possível com os fatos.

\subsubsection{Objetivo Final}

Diante de todo o conteúdo introdutório até agora redigido, o objetivo final do artigo é:

- Elencar melhorias de processos internos, apoiados na técnica Lean Manufacturing, através do mapeamento do fluxo processual de envio de notas fiscais para pagamento, entre a área da Tesouraria e a área Fiscal do setor Financeiro de uma empresa de varejo em artefatos de couro e artigos de viagem.

\subsubsection{Objetivos Intermediários}

A fim de permitir que o autor em questão possa chegar à uma conclusão geral mais próxima possível aos fatos da empresa, seguem abaixo os objetivos intermediários para a testagem das hipóteses, respectivamente ao conteúdo:

- Mapear os recentes processos com participação da área da Tesouraria no que tange ao envio de notas fiscais. 
- Identificar indicadores de desempenho a serem melhorados a fim de orientar as ações de aprimoramento dos processos, por meio da técnica de Lean Manufacturing das fontes de desperdícios.

- Redesenhar o fluxograma de processo de acordo com as oportunidades de melhorias identificadas para aperfeiçoamento e otimização do trabalho.

\subsection{Delimitação do Estudo}

O presente estudo se apoiou em informações e processos internos reais de uma empresa nacional de destaque no segmento de varejo em artefatos de couro e artigos de viagem, levando em consideração as observações profissionais no que tange à relação rotineira entre as áreas de Tesouraria e Fiscal do setor Financeiro no tocante aos pedidos de pagamentos que acompanham notas fiscais. Para isso, colaboradores de ambas as áreas foram escutados e selecionados para participar ativamente da elaboração do fluxo processual convergente das atividades no primeiro semestre de 2021.

Esse estudo considerou fatores pretéritos como forma de contextualizar o cenário atual a ser mencionado. Somado a isso, é válido destacar ainda que esse trabalho foi elaborado em paralelo e em andamento com um processo transitório real e ainda atual na empresa entre essas duas áreas: Tesouraria e Fiscal. Os dados e demais números apresentados ao longo do estudo se basearam em estimativas e médias aritméticas a partir de coleta de amostras a fim de validar as informações mais próximas e reais da empresa em cada uma das fases temporais divididas.

\subsection{Relevância do Estudo}

Quanto à relevância do estudo, é notório destacar que o presente artigo serve como uma consulta a um caso prático de análise real e concreta da relação de tarefas existentes entre as áreas de Tesouraria e Fiscal de uma empresa em destaque nacionalmente no segmento de varejo de artefatos de couro e artigos de viagem.

Como material inédito que aborda mapeamento de processos não antes vistos durante os quase 80 anos de história da empresa e que traduzem informações reais sobre atividades operacionais do setor Financeiro de uma empresa consolidada no mercado, o estudo em questão pode ser útil para outras empresas interessadas em aprimorar seus fluxos processuais internos não só no departamento Financeiro como também em outros setores. 
Assim como traz de maneira esquematizada uma situação real recorrente no ambiente financeiro de muitas outras empresas nacionais que ainda encontram limitações e gargalos processuais que precisam ser aprimorados, otimizados e modificados conforme as necessidades. Isso, independente do segmento de atividade econômica que atuam regional ou nacionalmente. $E$ além do ambiente financeiro, a metodologia em questão abordada nesse caso também se aplica a outros setores e departamentos não financeiros de uma empresa desde que a teoria seja convergente com o mapeamento da cadeia de tarefas. 


\section{Referencial Teórico e Contexto}

\subsection{Definição de Processos}

Para Oliveira (2007), processo é o conjunto estruturado de atividades distribuídas em sequências desde que as mesmas apresentem uma relação lógica entre si, com a finalidade de atender e suplantar as necessidades e expectativas dos stakeholders internos e externos, principalmente os clientes. Já os autores Araújo, Torres e Martines (2011) são mais diretos ao afirmarem que processo é um conjunto sequenciado de atividades formadas por tarefas e elaboradas com o objetivo de gerar um resultado que surpreenda o cliente.

O conceito de processo também é descrito por Sobral e Peci (2008) como um conjunto de atividades que pertence a um sistema operacional, que por sua vez é composto por entradas (como insumos), processos de transformação e saídas (como produtos e serviços). Nesse raciocínio, Slack, Chambers e Johnston (2009) definem processos como todas as operações que produzem bens e serviços através da transformação de entradas em saídas. Nas entradas, denominadas como inputs, estão os recursos a serem transformados, como materiais, informações e consumidores, e os recursos de transformação, como equipamentos e pessoal. Enquanto nas saídas, os outputs, estão os bens e serviços aos consumidores. Dessa forma, os autores definem processos como arranjos de recursos que produzem produtos e serviços, em que cada operação é composta por um conjunto de etapas interconectadas que se organizam em um fluxo de trabalho cuja saída de um processo é a entrada do outro.

Gonçalves (2000) também reforça o conceito anterior ao destacar que em uma atividade que toma um input, valores são adicionados a ele para que sejam formados outputs a um cliente específico, seja interno ou externo. Em raciocínio com o capítulo anterior quando se comentou sobre a importância do desenho de mapeamento inéditos nas organizações, Gonçalves (1997) enfatiza que todos os responsáveis pela gestão das empresas precisam constantemente redesenhar os sistemas internos, redefinir objetivos e delimitar metas visando a obtenção de ganhos maiores. Nesse paralelo, compreende-se o quão fundamental é alinhar o fluxo processual de cada setor com os demais a fim de que o modelo de gestão entre os agentes seja amadurecido para que as informações compartilhadas e conectadas entre as equipes tenham uma fluidez e gerem valores adicionais ao cliente.

Com base no que Gonçalves (2000) diz no início do parágrafo anterior, percebese que Rotondaro (2005) também compartilha uma abordagem de que os processos 
enquanto atividades sequenciadas e organizadas geram um valor agregado como consequência ao cliente. Já Campos (2004) verifica um enfoque de processo voltado para a gestão da qualidade a partir de uma relação direta em que um conjunto de causas (meios) podem influenciar e ocasionar em efeitos (fins e resultados).

\subsection{Mapeamento de Processos}

De acordo com Valle e Oliveira (2013), a modelagem de processos tem como objetivo documentar e registrar os processos de negócio em modelos a fim de que sejam modelados para prover dados de integração entre processos para fins de Tecnologia de Informação e de Qualidade.

Nesse mesmo ínterim, os autores defendem que o mapeamento de processos é uma técnica facilitadora e auxiliadora na análise de processos. A partir da incorporação de metodologias com a finalidade de compreender e visualizar os processos atuais de uma organização quando essas alinhadas com as metas e os objetivos estabelecidos da mesma, a análise de processos assimila informações oriundas de planos estratégicos, modelos de processos e medição de desempenho (VALLE e OLIVEIRA, 2013).

Quanto à esse último assunto da medição de desempenho, Campos (2004) argumenta que o mapeamento de processos está alinhado com os itens de controle, a fim de medir também os aspectos de qualidade, custos, valores e efeitos. Nessa perspectiva, há um complemento de que devem ser analisadas variáveis de desempenho e de resultados para que os efeitos e fins possam considerar as influências internas e externas que atuam sobre as etapas do processo (CAMPOS, 2004).

Diante da análise de variáveis de desempenho, é possível identificar, mensurar e averiguar quais os principais gargalos, desperdícios, travamentos, armadilhas e deficiências que atuam sobre as etapas dos processos. Segundo Valle e Oliveira (2013), o mapeamento de processo permite uma rápida identificação das limitações organizacionais associadas aos aspectos de: falta de padronização, ambiguidade, repetição, redundâncias, sobrecargas, excessos, omissões e carências.

\subsection{Gestão de Processos}

Nessa linha de raciocínio quando se considera a elaboração de processos, urge a necessidade de se utilizar as perspectivas de Gestão de Processos para que seja possível compreender os processos críticos que orientarão a organização (ARAÚJO, TORRES e MARTINES, 2011). De acordo com Almeida (2015), graças à gestão de processos, a organização possui capacidades de analisar, definir, executar, monitorar e 
gerenciar os fluxos de processos com mais efetividade visando vantagens competitivas no mercado. Isso, justamente conforme um dos pilares apresentados pelo programa Brasil Mais, do Ministério da Economia. De maneira geral, a gestão de processos visa alcançar a máxima eficiência na produtividade do funcionário quanto ao monitoramento, controle e fiscalização das etapas sequenciais de uma cadeia lógica que deve funcionar conforme o planejado dentro das limitações da visão organizacional (FUNDAÇÃO NACIONAL DA QUALIDADE, 2006).

O Gerenciamento de Processos de Negócio (BPM) é um conceito que une três tipos de abordagens: foco em tecnologias e sistemas de informação; foco na gestão de melhoria dos processos de negócio; e foco na gestão organizacional por processo de negócio (DEBRUIN e DOEBELI, 2009). Quanto à abordagem de aplicação de BPM, na área de tecnologia e sistemas de informação, compreende-se BPM como uma solução para negócios utilizando sistemas de software e tecnologias para automatização e gerenciamento (DEBRUIN e DOEBELI, 2009). Quanto ao foco em gestão e melhoria de processos de negócios, Debruin e Doebeli (2009) trazem essa abordagem para gerenciar e melhorar os processos com ênfase em seu ciclo de vida. Já para uma gestão da organização focada em processos de negócio, os autores entendem o BPM como uma abordagem para gerenciar uma empresa através da visão de processos de negócio com foco mais além desses mesmos processos de negócio.

Smith e Fingar (2003), como especialistas em Tecnologia da Informação, consideram o Gerenciamento de Processos de Negócios como uma automação de processos com base em ferramentas avançadas de software que monitoram 0 andamento e o fluxo dos processos de forma rápida e barata. Diante disso, os autores ressaltam que o BPM se trata de um enfoque complementar e mais avançado de otimização de transformação de processos que possui mais recursos atualizados frente ao movimento anterior da Gestão pela Qualidade Total (BPR). Nisso, o foco maior deve ser na melhoria e transformação de processos de negócios visando resultados promissores, tais como: aumento da produtividade, identificação de gargalos, eliminação dos desperdícios de tempo, redução da burocracia e satisfação dos clientes (SMITH e FINGAR, 2003).

\subsubsection{BPM (Business Process Management)}

Segundo Almeida (2015), o Business Processo Management (BPM) é o conjunto de práticas focadas na melhoria contínua dos processos de uma empresa cujo objetivo é integrar a estratégia que cada organização possui com as necessidades e expectativas que os clientes depositam em seus produtos e serviços. O BPM CBOK, 
corpo de conhecimento elaborado pela Association of Business Process Management Professionals (ABPMP), classifica o BPM como uma disciplina gerencial formada por um conjunto de práticas e princípios de gestão que são aplicados aos processos, dispensando demais classificações como metodologia, estrutura de negócios e conjunto de ferramentas.

Valle e Oliveira (2013) afirmam que o planejamento de BPM tem o propósito de definir as atividades de gestão por processos que contribuirão para o alcance das metas organizacionais através das análises dos fatores internos e externos. De acordo com Almeida (2015), o BPM abrange aspectos fundamentais da Administração, tais como: estratégia, objetivos, cultura, estruturas organizacionais, métodos e tecnologias.

Quanto à tópico da estratégia, Almeida (2015) defende que uma empresa que deseja atingir a visão de futuro adequada deve ter uma operação de processos alinhada com o planejamento estratégico e definida no plano de execução para que as ações necessárias sejam executadas na prática. Sobre o aspecto de objetivos, o respectivo autor argumenta que uma definição clara dos processos organizacionais proporciona uma performance melhor dos funcionários no que tange à entrega de valores aos clientes. Sobre o aspecto de cultura, é interessante destacar que muitas empresas atualmente não possuem uma cultura orientada aos processos, ou seja, os processos são singulares quando a liderança de cada um deles está limitada às tarefas de cada departamento da empresa, sem apresentar uma conexão e visão de ponto a ponta (ALMEIDA, 2015).

O mesmo autor ainda pontua que as estruturas organizacionais influenciam na gestão de processos, já que o líder que adota a disciplina gerencial do BPM deve possuir uma visão holística das funções de negócio que defenda a integração e a colaboração coletiva dos departamentos, ao invés de apenas delegar as funções para cada setor em específico. No que se refere ao método, Almeida (2015) colabora com uma visão construtiva de que as empresas devem ter um escritório de processos para auxiliar na perpetuação da metodologia e no alcance das melhorias e otimizações máximas das etapas.

Sobre o princípio da tecnologia, Almeida (2015) comenta sobre a possibilidade de se utilizar tecnologias para dar suporte aos processos e automatizar algumas funções. Para ele, nessa arquitetura de processos, o uso da tecnologia de informação deve traduzir a visão estratégia de um negócio empresarial, já que quanto mais tecnologia for aplicada para gerenciamento de dados, desenho e armazenamento de regras e monitoramento de informações, hardwares e aplicações; melhores serão as 
vantagens competitivas que uma organização terá frente aos seus concorrentes para mapear melhores alcances de entregas de valores aos clientes externos e internos.

\subsubsection{BPMN (Business Process Model and Notation)}

Segundo Almeida (2015), o Business Process Model and Notation (BPMN) é uma notação para modelagem de processos, considerada a mais moderna da atualidade por estabelecer uma relação gráfica entre símbolos e figuras, em que cada um deles possui uma regra definida para comportamento e reação dentro do processo.

Almeida (2015) ainda comenta que a notação BPMN surgiu diante de esforços conjuntos e coletivos entre várias empresas do segmento de ferramentas de modelagem. Durante sua criação, a notação de cada uma dessas empresas era considerada improdutiva, o que resultou na regulamentação de padrões tecnológicos uniformes e que hoje são mantidos em controle pelo Object Management Group (OMG), uma entidade internacional sem fins lucrativos.

Para Valle e Oliveira (2013), o BPMN é uma técnica utilizada para estabelecer a modelagem de processos por meio de um padrão tecnológico uniforme, em que a definição e a documentação de desses devem possuir os seus próprios padrões bem definidos. Por meio da modelagem de processo, Valle e Oliveira (2013) destacam que é possível compreender o relacionamento em três níveis: processos, subprocessos e atividades. Diante disso, Almeida (2015) complementa a ideia de que a percepção desses níveis deve se basear em uma visão holística e de ponta a ponta, a fim de compreender o resultado entre diversos departamentos da organização, e não apenas de uma única área, com o objetivo de gerar valor ao cliente.

Além disso, o BPMN também serve para: definir melhorias em processos já existentes, documentar e disseminar processos novos e já existentes, automatizar processos já definidos, definir novos fluxos de trabalho, ajudar na identificação dos requisitos de software e definir melhorias em processos já existentes. Ao defender que a notação BPMN descreve uma sequenciação lógica do passo a passo de um processo por meio de diagramas, Almeida (2015) destaca vantagens dessa técnica, tais como: linguagem gráfica fácil de ser compreendida por todos, versatilidade e compatibilidade por ser aplicada em diversos tipos de processos como administrativos, financeiros, operacionais, controle de qualidade e desenvolvimento de produtos.

Quanto aos elementos gráficos e simbologias do BPMN, destacam-se quatro grupos: objetos de fluxo, artefatos, objetos de conexão e swimlanes.

I - Objetos de Fluxo (Flow Objects): se dividem em outras três arestas; 
a) Atividades (Activities): representadas pela figura do retângulo, são aquilo que precisa ser executado dentro de um processo, a partir de uma sequência de passos e de níveis de trabalho que venham a indicar as ações executadas por um agente para agregar valor ao resultado final.

b) Eventos (Events): representados pela figura do círculo, são as situações que ocorrem dentro de um processo, estando presentes no início, meio e fim do fluxo total.

c) Decisores (Gateways): representados pela figura do losango, são as condicionais que indicam o direcionamento do fluxo de acordo com as possibilidades e caminhos definidos.

II - Artefatos (Artifacts): são utilizados no esquema para agregar informações complementares em cima das atividades descritas no desenvolvimento do processo, tais como: objetos de dados, grupos e anotações;

III - Objetos de Conexão (Connecting Objects): representam setas e direcionamentos que indicam o movimento de um ponto para o outro, bem como a conexão entre os objetos de fluxos, sendo o mais frequente o fluxo de sequência;

IV - Swimlanes: organizam as atividades em categorias separadas que agem de forma integrada e conectada de acordo com cada agente envolvido no processo, ou seja, de acordo com as lanes (raias) de cada departamento e papel que compõem a pool (piscina).

\subsubsection{Bizagi Modeler}

Para esse artigo em questão, o software de notação e modelagem de negócios baseado no padrão BPMN e utilizado para a avaliação de processos que envolvem o setor Financeiro da empresa em estudo foi o Bizagi Modeler. Lima (2016) elogia o Bizagi Modeler como uma ferramenta imprescindível para a modelagem de processos de negócios e que facilita o cotidiano de profissionais que necessitam de uma ferramenta capaz de desenvolver fluxogramas sobre setores de uma organização.

\subsection{Introdução à Teoria da Manufatura Enxuta}

Conforme Chiavenato (2000), a Abordagem Sociotécnica desenvolvida na década de 50 foi um modelo voltado para a ênfase na organização como um sistema aberto em interação constante com o seu ambiente formado por dois outros subsistemas: o social e o técnico. Nela, a Teoria da Manufatura Enxuta foi um dos ramos dessa abordagem. 
O Sistema Lean Manufacturing (traduzido ao português como Manufatura Enxuta) é um sistema de produção desenvolvido pela empresa Toyota, no Japão, a partir da contribuição de dois funcionários do fabricante automotivo: Taiichi Ohno e Eiji Toyoda (ALVAREZ e ANTUNES, 2001). A palavra de língua inglesa lean tem como tradução ao português para "enxuto". Conforme o dicionário Aurélio, o termo "enxuto" é um adjetivo que caracteriza aquilo que se enxugou. Já a palavra manufacturing, que significa manufatura em português, no vocabulário inglês possui um sentido mais característico para produção industrial. Justamente nessas definições, Manufatura Enxuta se relaciona com a ideia de um sistema de produção industrial mais enxuto no que tange aos gastos e aos desperdícios. A locução em inglês foi cunhada pelos autores James Womack, Daniel Jones e Daniel Ross no livro "A Máquina que Mudou o Mundo", publicado em 1990.

Para entender o surgimento dessa teoria, é necessário retornar para o contexto da Segunda Guerra Mundial, fase em que o Japão teve sua economia devastada, precisando criar um sistema que envolvesse pouco estoque, fluxo de caixa curto e eficiência na produção para manter a qualidade do produto e do serviço (BALARDIM, 2019). Agonizada por conta do período pós-guerra no Japão, a fabricante de automóveis Toyota criou então um dos sistemas de produção mais inovadores de todos os tempos (SOBRAL e PECI, 2013).

Isso se sustenta porque, nesse espaço de tempo, dois colaboradores da empresa Toyota perceberam o perigo que seria copiar o sistema americano de produção em massa em função das extensões territoriais dos dois países serem diferentes e do mercado consumidor do local exigir uma variedade de produtos. Ainda nesse cenário, a economia japonesa não estava apta a adquirir tecnologias do Ocidente e o mercado do país demandava uma variedade grande de produtos que exigia produções em pequenos lotes ao contrário da ideia do Fordismo (BALARDIM, 2019). Assim, um grupo de engenheiros japoneses incluindo Ohno e Toyoda visitou as fábricas da Ford nos Estados Unidos para aprender ainda mais sobre o modelo em questão. $\mathrm{Na}$ visão dos engenheiros, o Fordismo estava ultrapassado porque eram produzidas peças em alta escala e que resultavam em excesso de estoque parado e desperdício de materiais. Conforme enfatizado por Sobral e Peci (2013), o modelo então classificado como toyotista se apresentou como uma alternativa mais eficiente frente ao modelo fordista de produção, que explorava as vantagens da produção em série.

Diante disso, com o nome de Sistema Toyota de Produção, antes de se firmar como Manufatura Enxuta, surgiu esse novo modelo na década de 50, cujo objetivo 
principal era alinhar a melhor sequência lógica de trabalho a fim de agregar maior valor aos clientes e aumento de produtividade e de eficiência dos trabalhadores (JONES e WOMACK, 1998). Para atingir essas finalidades, os meios para alcance desse objetivo seriam: evitar desperdícios, minimizar os estoques, reduzir o tempo de espera, identificar os inventários desnecessários, eliminar os gargalos de transporte, agilizar a produção e melhorar o ambiente de trabalho (JONES E WOMACK, 1998).

Sobral e Peci (2013) destacam que o modelo toyotista consiste em uma produção e cadeia de suprimento enxuta, flexível e altamente terceirizada, que prevê a máxima eliminação possível dos estoques e a busca constante pela agilidade no processo produtivo. Para os autores, com uma produção de visão mais enxuta, a fabricante Toyota se destacou pelo uso inovador dos sistemas just-in-time, pela promoção de conhecimento nas redes de parceiros, pela flexibilidade no chão da fábrica, pela agilidade para incorporar novas tecnologias e pelo estudo profundo sobre o perfil dos consumidores.

\subsection{Características da Manufatura Enxuta}

Balardim (2019) define o Lean Manufacturing como praticamente uma filosofia, mais além do que uma simples metodologia, já que a mentalidade enxuta que o sistema propôs deve ser mais absorvida e cultivada na cultura organizacional das empresas nos tempos atuais. E atualmente, esse sistema se baseia na redução de desperdícios divididos em oito categorias, segundo Balardim (2019).

I - Transporte: realizar qualquer movimento de ferramentas, estoque, equipamentos e produtos além do necessário;

II - Estoque: excessividade de recursos parados;

III - Movimentação: deslocamentos de um funcionário;

IV - Espera: ociosidade de recursos durante operações;

V - Superprodução: produção mais cedo e/ou em maior quantidade do que o necessário;

VI - Processamento Excessivo: operações em excessos que não agregam valor adicional ao cliente;

VII - Retrabalho: atividade de repetição ou correção de um processo anteriormente defeituoso; 
VIII - Intelectual: conhecimentos e capacidades dos colaboradores que não são devidamente aproveitadas pela empresa.

Somado a isso, Jones e Womack (1998) destacam cinco princípios que devem ser seguidos pelas organizações a fim de que o sistema de implementação das técnicas de Manufatura Enxuta realmente seja completo. Na visão dos autores, esses conceitos devem ser seguidos cronologicamente na ordem original apresentada por eles. Os cinco princípios da Manufatura Enxuta, respectivamente, segundo os autores são:

I - Valor: as empresas devem focar no cliente como o agente oficial que irá definir o que é valor na sua perspectiva, já que o mesmo considera o quão ele está disposto a pagar um valor mais caro por um produto ou serviço e o quanto isso atende às suas necessidades básicas desde que tenha viavelmente um preço dentro de suas margens definidas (BALARDIM, 2019);

II - Fluxo de Valor: conjunto de atividades, sequenciadas ou não, que agregam ou não valor ao cliente, realizadas por uma empresa para que um produto ou serviço passe a da concepção ao lançamento (BALARDIM, 2019). Segundo Hines e Taylor (2000), é composto por três tipos de fluxos - de materiais, de informações e de pessoas;

III - Fluxo Contínuo: capacidade que uma empresa tem de produzir ou prestar um serviço sem interrupções para atender às expectativas dos clientes com rapidez e celeridade, incluindo, por exemplo, processar pedidos com agilidade para garantir um volume de estoque baixo segundo Balardim (2019);

IV - Produção Puxada: os produtos são fabricados apenas quando há uma solicitação de nova demanda por parte do cliente, eliminando a necessidade de estoque já que os mesmos vão direto ao ponto de venda e opondo ao conceito de produção empurrada com previsão de demanda (BALARDIM, 2019);

V - Perfeição: proposta que reforça o conceito da importância de redução dos desperdícios como uma prática de rotina a ser amadurecida na organização, visando manter a qualidade do produto e serviço para não afetar na percepção do valor final oferecido ao cliente segundo Balardim (2019).

\subsection{Sobre a Empresa}

De modo a apresentar um conteúdo institucional que aborda características e detalhes sobre a empresa de varejo de artefatos de couro e artigos de viagem selecionada para esse estudo de caso, foram colhidas diversas informações internas e 
institucionais a fim de sustentar o trabalho com um melhor entendimento sobre pilares do assunto em questão.

\subsubsection{História}

Sinônimo de tradição, a empresa em questão é destaque nacionalmente na comercialização de malas, bolsas, pastas, carteiras, artefatos de couro e acessórios para viagem, desde sua na década de 40. A marca se destaca principalmente pela qualidade, variedade, preço e bom gosto de seus produtos. Atualmente, ela está presente nas principais capitais brasileiras em mais de 140 pontos de venda. No início, a empresa era reconhecida apenas como especialista em vendas de malas e artigos masculinos mas, com o passar dos anos, o foco foi se ampliando, visando atingir um maior número de consumidores com a venda de novos artefatos de couro.

Hoje, o mercado-alvo da marca é composto por executivos, mulheres e crianças. A venda de malas continua sendo o "carro-chefe" da empresa, além da venda de artigos de couro e escolar, que cresce cada vez mais. Baseado neste segmento, ela oferece como vantagem competitiva diferentes formas de pagamento e maiores prazos, além de efetuar entregas em locais de difícil acesso. A marca trabalha com uma grande variedade de produtos, incluindo várias linhas exclusivas nacionais e internacionais, todas altamente conceituadas no mercado. Além de fabricar alguns produtos de marca própria, com a mesma qualidade e bons preços.

Tendo como missão "Democratizar produtos exclusivos de excelente qualidade com uma marca brasileira desejada", a marca atinge as principais capitais brasileiras com um grande plano de expansão. Isso se explica porque a empresa possui como visão "Liderar o mercado latino-americano, tornando-se referência do segmento no dia a dia dos clientes".

Ainda sobre o ambiente interno, a sede administrativa da empresa, situada no Rio de Janeiro, possui aproximadamente 70 colaboradores que auxiliam em diversos setores da companhia, tais como: Logística, Compras, Marketing, Design Gráfico, Ecommerce, Tesouraria, Contabilidade, Fiscal, Auditoria, Inteligência de Negócios, Jurídico, Serviços de TI e Recursos Humanos. Em relação aos detalhes da Logística, é importante destacar que a marca possui uma fábrica e um armazém próprios. Considerando assim os funcionários que trabalham nas 145 lojas da empresa, no escritório, na fábrica e no armazém, ao todo são aproximadamente 500 colaboradores que trabalham atualmente para a empresa em todo o Brasil. 


\subsubsection{Mercado}

Quanto ao setor de atuação da empresa voltada para varejo de acessórios como artefatos de couro e itens de viagem, destaca-se novamente que a empresa é referência como franquia nacional de artigos como malas, bolsas, pastas, carteiras e acessórios para viagem há décadas.

Em relação à participação da marca no cenário nacional, a mesma possui 145 lojas físicas espalhadas em 21 unidades federativas do Brasil, sendo 86 delas lojas próprias e 59 como franquias. A maioria das lojas está situada na Região Sudeste, com maior concentração sendo no Estado do Rio de Janeiro com 66 lojas, local esse também sede do escritório administrativo da empresa. Na sequência, os Estados com maior número de lojas são Minas Gerais e Rio Grande do Sul, com 12 e 11, respectivamente.

A Tabela 1 e o Gráfico 1 apresentam mais informações a respeito da distribuição de lojas da empresa pelo Brasil.

Tabela 1: Lojas no Brasil

\begin{tabular}{|c|c|c|}
\hline Região & Lojas & Percentual \\
\hline Sudeste & 86 & $59,31 \%$ \\
Sul & 23 & $15,86 \%$ \\
Nordeste & 19 & $13,10 \%$ \\
Centro-Oeste & 10 & $6,90 \%$ \\
Norte & 7 & $4,83 \%$ \\
\hline
\end{tabular}

Fonte: Elaborado pelo autor com base em informações da empresa.

\section{Gráfico 1: Distribuição Regional das Lojas pelo Brasil}

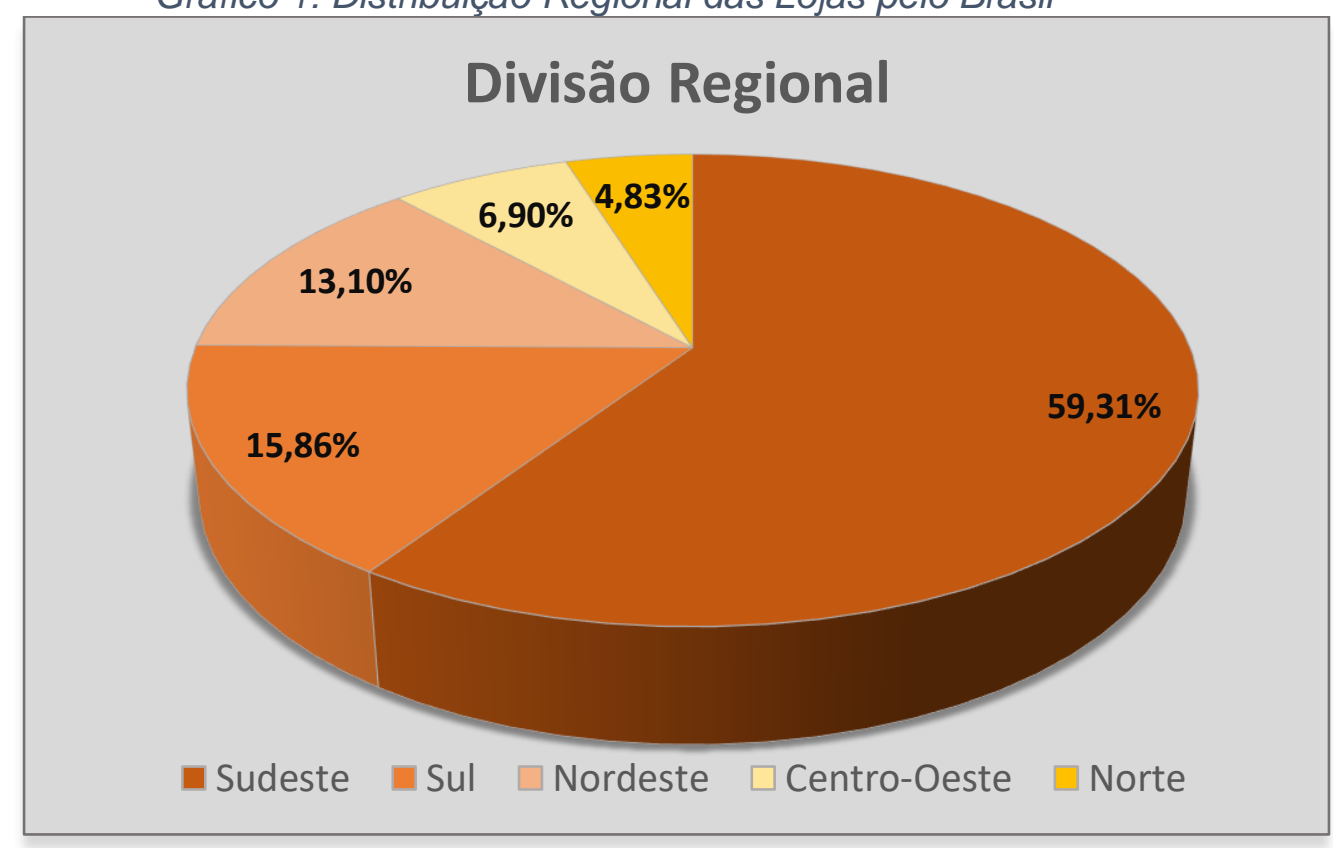

Fonte: Elaborado pelo autor com base em informações da empresa. 
Em relação ao faturamento da empresa nos últimos dois anos, a Tabela 2 apresenta o percentual de faturamento de vendas trimestralmente nos últimos dois anos considerando as vendas que ocorreram por e-commerce e as vendas em lojas físicas.

Tabela 2: Faturamento Percentual de Vendas

\begin{tabular}{|l|cccc|}
\hline & $1^{\circ}$ tri 2019 & $2^{\circ}$ tri 2019 & $3^{\circ}$ tri 2019 & $4^{\circ}$ tri 2019 \\
\hline E-commerce & $1,54 \%$ & $2,05 \%$ & $2,73 \%$ & $2,41 \%$ \\
Lojas Físicas & $98,46 \%$ & $97,95 \%$ & $97,27 \%$ & $97,59 \%$ \\
\hline
\end{tabular}

\begin{tabular}{|l|cccc|}
\hline & $1^{\circ}$ tri 2020 & $2^{\circ}$ tri 2020 & $3^{\circ}$ tri 2020 & $4^{\circ}$ tri 2020 \\
\hline E-commerce & $2,09 \%$ & $30,42 \%$ & $6,15 \%$ & $4,56 \%$ \\
Lojas Físicas & $97,91 \%$ & $69,58 \%$ & $93,85 \%$ & $95,44 \%$ \\
\hline
\end{tabular}

Fonte: Elaborado pelo autor com base em informações da empresa.

$\mathrm{Na}$ imagem, é válido destacar o crescimento do e-commerce a partir do segundo trimestre de 2020 tendo em vista as questões da pandemia cujos Estados decretaram lockdown de diversos comércios de ruas e de shopping. Por isso, o e-commerce ganhou destaque e crescimento significativo devido às compras impulsionadas pela internet.

Dentro do setor de mercado do segmento de artefatos de couro e artigos de viagem, a marca possui parcerias com duas principais empresas: Swisswin e Travelcross. Isso se sustenta porque a empresa se destaca no setor quando o assunto é o seu mix de produtos de alta qualidade frente aos concorrentes, considerando que malas, frasqueiras, sacolas de viagem e necessaires são as principais linhas da marca.

Como outro ponto diferencial frente aos concorrentes, a empresa evoluiu principalmente pela sua linha Fitness, um segmento criado para atender um nicho de mercado que se encontra em expansão, tendo hoje produtos que são os best sellers de vendas em todas as lojas do Brasil, em destaque para as garrafas térmicas. A marca também é referência no segmento da linha feminina, em que as equipes de produtos projetam e desenvolvem acessórios de estilo como bolsas, carteiras e itens para mulheres, que combinam tendência, conforto e praticidade. Sobre a linha masculina, seja para o trabalho ou momentos de lazer, a companhia tem um mix completo de produtos para o público em questão como pastas, mochilas, carteiras e diversos artigos de couro nacionais e internacionais.

Além dessas linhas, a empresa possui uma parceria rara no Brasil para adquirir produtos licenciados da Disney, Marvel, Star Wars e Nickelodeon no que se refere ao mix de produtos exclusivos da linha infantil como malas e mochilas escolares. 


\subsubsection{Setor Financeiro}

O setor Financeiro da companhia abrange a gestão das atividades de Tesouraria, Contábil, Fiscal, Planejamento e Inteligência de Negócios. Ao gerente de Finanças, estão atribuídas as seguintes tarefas: modelagem e planejamento econômico-financeiro do negócio; apuração e análise de resultados e indicadores de diversas naturezas; captação de recursos e gestão de relações bancárias; construção e monitoramento do plano orçamentário; e otimização de processos visando aumento de governança e eficiência.

\subsection{4 Área da Tesouraria}

A área de Tesouraria da empresa abrange as coordenações dos nichos do Contas a Pagar, do Contas a Receber e da Conciliação Bancária. Quanto à essa área, destacam-se responsabilidades como: automatização de processos; reclassificação de despesas; inclusão de pagamentos em instituições bancárias; lançamentos de títulos no sistema de ERP; desenvolvimento de relatórios gerenciais; verificação de pendências de pagamentos; conciliação bancária diária; cobrança de devedores; e gerenciamento de caixa das lojas. A área é composta atualmente por 8 membros na equipe, sendo 1 coordenadora, 3 analistas, 2 assistentes, 1 estagiário e 1 jovem-aprendiz.

Quanto às atividades, a área possui responsabilidade com o gerenciamento do caixa das filiais que pertencem ao grupo empresarial, já que se considera todo o dinheiro que abrange as lojas físicas em shoppings e em ruas, o Centro de Distribuição, a fábrica, o armazém, o e-commerce, as franquias administradas e o ambiente patrimonial e familiar dos sócios.

\subsection{5 Área Fiscal}

A área Fiscal da companhia engloba colaboradores que exercem os cargos de analistas, assistentes e estagiários, majoritariamente com vínculo ao ensino superior em Ciências Contábeis. Quanto à essa área que atualmente é braço direito da Tesouraria, destacam-se as seguintes responsabilidades: classificar e lançar notas fiscais dentro do prazo de vencimento dos pedidos; controlar recebimentos de notas fiscais; apurar e calcular impostos; e elaborar declarações acessórias. A área é composta atualmente por 7 membros na equipe, sendo 1 coordenadora, 3 analistas e 3 estagiários.

Essa área atualmente está em expansão na empresa por acumular uma nova tarefa ainda em aprimoramento e que foi justamente o foco durante a montagem do processo: o lançamento de notas fiscais no sistema ERP da empresa. Por sua vez, essa tarefa que antes era dividida entre as áreas Fiscal e de Tesouraria, passou a ser de total 
responsabilidade da primeira pois se trata da análise de notas fiscais que podem conter retenções de impostos. Dessa forma, tornou-se imprescindível estudar e analisar o relacionamento entre a Tesouraria e o Fiscal no que tange à essa mudança na empresa com a finalidade de que todos os agentes envolvidos busquem um padrão de trabalho que atenda à otimização.

Por esse motivo, se sustenta a preocupação nesse estudo de caso em propor uma análise integrada sobre as tarefas de ambas as áreas no que tange ao provisionamento de pagamentos que contêm notas fiscais. 


\section{Diagnóstico da Situação Problema e Oportunidade}

Diante de observações ao longo de 2020 sobre as relações entre as equipes de Tesouraria e do Fiscal da empresa em estudo no que tange ao provisionamento de pagamentos que acompanham notas fiscais, foi identificado principalmente que a comunicação entre ambas as áreas durante o processo em específico deve ser a mais otimizada possível a fim de atingir às expectativas de todos.

Para que se atinja esse objetivo e de acordo com o que Lucinda (2010) comentou sobre atender às necessidades dos clientes, foi necessário comparar três cenários dessa rede de relacionamento nos últimos 12 meses. Nesse capítulo em específico, foi comentado o que se observou nas duas primeiras fases já encerradas, com a finalidade de diagnosticar como se dirigiram esses processos de relacionamento ao longo do tempo.

\subsection{Fase I: Julho a Dezembro de 2020}

Em um primeiro momento, foi diagnosticado o fluxo de processos correspondente à fase do último semestre de 2020, época a qual a equipe do Fiscal ainda não atuava no processo em si. A partir da montagem do primeiro processo referente ao período citado, com base na ferramenta do Bizagi Modeler, foi possível calcular o tempo das etapas a fim de diagnosticar as observações levantadas com base nas técnicas da Manufatura Enxuta e de acordo com os princípios mencionados por Jones e Womack (1998).

\subsubsection{Apresentação do Fluxograma do Processo}

Sobre o ano de 2020, é necessário comentar inicialmente que as áreas de Tesouraria e Fiscal trabalhavam frequentemente de maneira isolada entre si, já que o provisionamento de notas fiscais para pagamento era executado por uma empresa de Contabilidade terceirizada que não era tão próxima do time da Tesouraria. A principal comunicação entre os setores era baseada em mensagens escritas por meio da troca de e-mails nas contas corporativas de cada um dos colaboradores, sem uma constante comunicação verbal ou contato físico e presencial com a equipe da outra área.

O esquema da Figura 1 apresenta o fluxo de comunicação que existia em 2020 entre a equipe terceirizada e a equipe interna da Tesouraria, considerando principalmente a variável do tempo médio de cada atividade a fim de se realizar observações e análises sobre os dados apontados nessa primeira fase. A Tabela 3 indica os tempos das atividades do processo. 
Tabela 3: Dados do Fluxograma do Primeiro Processo

\begin{tabular}{|c|c|c|c|}
\hline Etapa & Agente & Descrição & Tempo Médio (Min:Seg) \\
\hline 1 & Solicitante & Encaminhar e-mail com a nota de serviço para pagamento & $01: 30$ \\
\hline 2 & Estagiário Tesouraria & Conferir o e-mail enviado & $00: 30$ \\
\hline 3.1 & Estagiário Tesouraria & Realizar o lançamento do valor cheio da nota & 04:00 \\
\hline 3.2 & Estagiário Tesouraria & Realizar o lançamento do valor líquido da nota & 04:00 \\
\hline 4.1 & Estagiário Tesouraria & Encaminhar e-mail ao solicitante confirmando o lançamento & $01: 30$ \\
\hline 4.2 & Estagiário Tesouraria & $\begin{array}{l}\text { Encaminhar e-mail à empresa terceirizada solicitando } 0 \\
\text { lançamento dos impostos }\end{array}$ & $01: 30$ \\
\hline 5 & Analista 1 Tesouraria & Visualizar o pagamento na planilha interna do setor & $00: 05$ \\
\hline 6 & Analista 1 Tesouraria & Localizar o documento anexo da respectiva nota & 01:00 \\
\hline 7 & Analista 2 Tesouraria & Incluir o pagamento manualmente na instituição bancária & 03:30 \\
\hline
\end{tabular}

Fonte: Elaborado pelo autor com base em informações calculadas da empresa.

Figura 1: Fluxograma do Mapeamento do Primeiro Processo

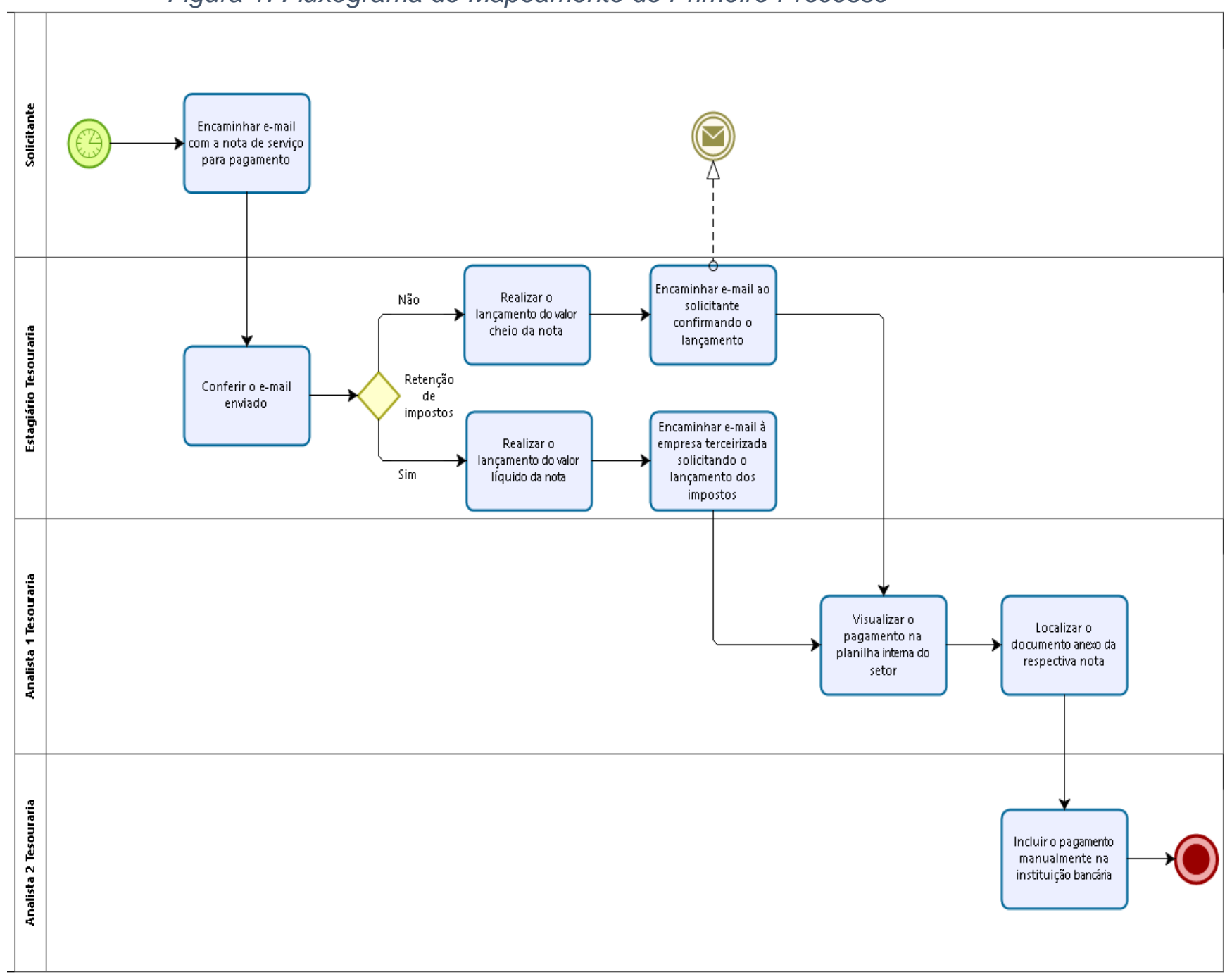

Fonte: Elaborado pelo autor com base em informações calculadas da empresa. 


\subsubsection{Diagnóstico do Fluxograma do Processo}

Como se observou na Figura 1, o trabalho entre todos os agentes durante esse período se resumia da seguinte maneira. A equipe da Tesouraria recebia os e-mails de diversos colaboradores de outros setores da empresa, aproximadamente 15 pessoas, com os pedidos de solicitação de pagamentos que acompanham notas fiscais. Nisso, aquelas notas fiscais que não apresentavam informações de retenção de impostos, tais como: ISS, PIS, COFINS, CSLL, PASEP, IRPJ, entre outros, eram lançadas integralmente pela equipe da Tesouraria. Para essas situações, a empresa de Contabilidade terceirizada não era acionada por não haver qualquer imposto embutido no serviço informado pela nota para provisionamento de pagamento. Essa etapa de checagem era realizada pelo time da Tesouraria, que apenas acionava a empresa de Contabilidade terceirizada quando identificada a retenção de impostos.

Por outro lado, quando era verificado que os e-mails tinham notas fiscais informando na última linha do arquivo que o valor líquido a pagar era diferente do valor cheio e em negrito da nota, ou seja, apresentando divergência com o valor principal cheio da nota; a orientação encaminhada era de que a equipe da Tesouraria deveria efetuar o lançamento da nota no sistema ERP da empresa considerando apenas o registro do valor líquido indicado. As retenções de impostos que representavam a diferença entre o valor total da nota e o valor líquido eram lançadas e registradas posteriormente e à parte no sistema pelos 2 funcionários da empresa de Contabilidade terceirizada, que registravam o rateio dos impostos embutidos no serviço.

Nesse processo, a comunicação entre as áreas era mínima, já que o e-mail disparado solicitando ao time terceirizado o lançamento das retenções de impostos geralmente não era respondido pelos seus funcionários, deixando em subentendido uma confiança de que o outro colaborador receptor visualizaria o e-mail e realizaria o provisionamento dos impostos da nota já lançada pelo valor líquido a pagar ao fornecedor. Devido à falha na comunicação, o esquema dos processos nesse período não considerou as estimativas de tempo das etapas da empresa terceirizada, pois não foi possível entrar em contato com os mesmos a fim de calcular o tempo médio realizada nos lançamentos dos impostos. Devido a isso, as estimativas indicam que o processo total da figura, se acrescentar essa etapa não registrada e calculada, seguramente ultrapassa o tempo de 19 minutos. Já que após a etapa 4.2 está subentendido que o processo seguia com o comando da equipe terceirizada.

Por conseguinte, as etapas finais eram realizadas pela própria Tesouraria, tais como: localização dos anexos para pagamento na data de vencimento e inclusão do 
pagamento manualmente na instituição bancária. Nesse período, destaca-se o fato de que a empresa em questão não trabalhava com nenhuma ferramenta no sistema ERP que permitisse o pagamento na instituição bancária por inclusão online, uma novidade que só chegou em definitivo à companhia em janeiro de 2021. Dessa forma, os pagamentos eram realizados integralmente por inclusão manual por uma das analistas da Tesouraria, que recebia o anexo com as informações de pagamentos para incluir manualmente no banco a partir da digitação do código de barras ou dos dados bancários para depósito.

Analiticamente, em relação aos tempos mencionados em cada atividade, devese destacar os seguintes pontos diagnosticados nesse caminho. Com base nas fontes de desperdício da Manufatura Enxuta, destaca-se que o envio de e-mail à empresa de Contabilidade terceirizada se tratava de um processo excessivo tendo em vista que o email disparado pelo solicitante em questão já poderia ser direcionado à equipe da retenção de impostos sem a necessidade de delegar essa função para algum membro da Tesouraria. Para facilitar esse processo, bastava o colaborador do outro setor acessar a nota e verificar se ela possuía ou não alguma retenção, descartando os emails que não tinham retenção e lançando no sistema ERP da empresa apenas aquelas que tivessem retenção. Delegando essa função para a Contabilidade terceirizada, isso permitiria que não houvesse atrasos de envios de e-mails de retenção de impostos caso algum colaborador da equipe da Tesouraria se atrasasse para realizar a sua tarefa. Dessa forma, seria evitado o recurso de um e-mail parado na caixa de entrada da equipe da Tesouraria tendo em vista o atraso para encaminhamento ao time da Contabilidade terceirizada.

Diante então da tabela analisada e conforme o parágrafo anterior, verificaramse em 2020 duas principais fontes de desperdícios da Manufatura Enxuta: (1) Estoque e (2) Processamento Excessivo. A primeira delas, justificada pela quantidade de e-mails na caixa de entrada que ficavam parados e sem resposta para a empresa de Contabilidade terceirizada tendo em vista a demora ou atraso para análise da nota por parte de alguém da equipe de Tesouraria. E a segunda explicada pelo fato de que era responsabilidade da equipe de Tesouraria enviar os e-mails para a equipe de Contabilidade Terceirizada indicando a retenção ou não de impostos na nota.

\subsubsection{Oportunidade Diante do Fluxograma do Processo}

Com base nessas observações também atestadas e verificadas pelo setor Financeiro, a principal questão observada pela equipe na época se tratava do baixo nível de comunicação direta entre a equipe de Tesouraria e a empresa de Contabilidade 
terceirizada, já que na maioria dos casos não tinha qualquer resposta dessa equipe quanto ao lançamento das retenções de impostos no sistema ERP da empresa, tanto que não foi possível mensurar no processo anterior o tempo médio das etapas sob responsabilidade da outra equipe. Bem como não foi realizado qualquer relatório para verificar se a empresa deixou de registrar algum imposto retido por falta de direcionamento de e-mails, falta de visualização dos e-mails ou falha humana de algum colaborador com o lançamento de informações na ferramenta ERP.

Assim, desse ponto de vista, a empresa estava carente de informações concretas sobre o nível de qualidade e a taxa de lançamentos do setor, já que conforme a definição hierárquica do organograma da empresa, essa área era independente das demais por ser terceirizada e não reportava informações diretas para qualquer superior interno da empresa em estudo.

Por esse motivo principal, dessas indefinições quanto ao lançamento ou não dos impostos pelo receptor, urgiu a necessidade de que esse controle fosse monitorado de maneira interna pelo próprio setor Financeiro da empresa. Nesse momento, a decisão imediata tomada pela alta gestão foi a de que para o ano de 2021 todo o processo a cargo da empresa de Contabilidade externa seria transferido para a equipe do Fiscal, inicialmente com um monitoramento paralelo executado pelo time da Tesouraria. Afinal, não se sabia o número ou percentual exato de quantos e-mails eram respondidos nem de quantos impostos realmente eram retidos ou deixados de ser retidos até o vencimento. Por conta dessa insegurança e incerteza, a visão da Tesouraria não alcançava a outra equipe da empresa terceirizada. Com as mudanças sugeridas, a finalidade principal seria aumentar o grau de interação entre a Tesouraria e a área tributária da empresa nos primeiros meses de 2021.

Diante das primeiras oportunidades da época, a Tabela 4 apresenta a lista de atividades sobre a ideia inicial que foi projetada pelo setor Financeiro sobre como poderiam ocorrer os novos processos com a presença da área do Fiscal na rede de comunicação, em face da substituição das atividades que antes eram realizadas pela empresa de Contabilidade externa. 
Tabela 4: Dados do Fluxograma do Processo Projetado

\begin{tabular}{|c|l|c|l|}
\hline Etapa & \multicolumn{1}{|c|}{ Agente } & Descrição & \multicolumn{1}{|c|}{ Tempo Médio (Min:Seg) } \\
\hline 1 & Solicitante & Encaminhar e-mail com a nota de serviço para pagamento & $01: 30$ \\
2 & Estagiário Fiscal & Conferir o e-mail enviado & $00: 30$ \\
3 & Estagiário Fiscal & Realizar o lançamento da nota & $04: 00$ \\
4 & Estagiário Fiscal & Encaminhar e-mail à Tesouraria confirmando o lançamento & $00: 30$ \\
5 & Assistente Tesouraria & Conferir se o lançamento da nota está correto & $00: 30$ \\
6.1 & Assistente Tesouraria & Solicitar revisão do lançamento da nota & $01: 00$ \\
6.2 & Estagiário Fiscal & Realizar a alteração do lançamento da nota & $02: 00$ \\
6.3 & Estagiário Fiscal & Encaminhar e-mail com a confirmação da alteração & $00: 30$ \\
7 & Assistente Tesouraria & Inserir o código de barras/dados para depósito no lançamento & $01: 00$ \\
8 & Assistente Tesouraria & Encaminhar e-mail ao solicitante confirmando o lançamento & $00: 30$ \\
9 & CE0 & Aprovar o prosseguimento do pagamento & $02: 00$ \\
10 & Assistente Tesouraria & Visualizar se o pagamento online foi incluído & $00: 30$ \\
11.1 & Assistente Tesouraria & Encaminhar o pagamento à parte para inclusão manual & $01: 00$ \\
11.2 & Analista 2 Tesouraria & Incluir o pagamento manualmente na instituição bancária & $02: 00$ \\
\hline \multicolumn{2}{|c}{} & Tempo Total & 17 minutos e 30 segundos \\
\hline
\end{tabular}

Fonte: Elaborado pelo autor com base em informações calculadas da empresa.

Esse mesmo esquema apresentado brevemente nesse tópico serviu para fins comparativos com a realidade no início do ano de 2021, justificado e explicado a seguir.

\subsection{Fase II: Janeiro a Abril de 2021}

No ano de 2021, houve duas fases divididas no primeiro semestre: a primeira delas considerando o processo transitório de janeiro a abril com a substituição da empresa terceirizada pela área Fiscal do setor Financeiro interno da empresa em estudo.

Nessa proposta, a realidade financeira da empresa mudou tendo em vista os primeiros meses da gestão a cargo de um novo CEO. Após verificar que o processo de 2020 descentralizava as equipes ao direcionar os pedidos de pagamentos para duas áreas diferentes e isoladas, foi tomada a decisão de centralizar e unificar os lançamentos: valor líquido com retenção de impostos e valor cheio isento de retenções.

Conforme as mudanças propostas para a empresa no ano de 2021 , foi diagnosticado que a área Fiscal da companhia deveria ter uma maior interação e colaboração com a Tesouraria, sendo então responsável pelo lançamento e registro integral de todos os pedidos de pagamentos na empresa que acompanham notas fiscais, tanto do valor líquido quanto da retenção de impostos quando houver. Diante dessa percepção de mudança urgente no processo como um todo, foi estimado que definitivamente a partir do mês de maio de 2021 a equipe da área Fiscal se responsabilizaria integralmente por todos os lançamentos dos valores embutidos nas notas fiscais e pedidos. 
Tendo em vista que se tratava de um processo transitório e inédito na equipe do Fiscal, ordenou-se que a equipe da Tesouraria dividisse o trabalho com o Fiscal pelos primeiros quatro meses do ano, de janeiro a abril. Nisso, novas atribuições foram direcionadas à Tesouraria com o intuito de que essa área treinasse os colaboradores da outra área sobre como realizar os lançamentos no sistema ERP da empresa. Nessa época, dois novos estagiários foram agregados ao time do Fiscal em janeiro de 2021 visando o crescimento interno da equipe para atender ao volume maior de lançamentos de notas. Por esse motivo, os quatro meses foram intensos com treinamentos completos e inéditos para que as mudanças fossem as mais rápidas possíveis desde que atendessem ao padrão de qualidade solicitado pela alta gestão, o que justificou um aumento total do tempo despedido com o processo plausível de interpretação.

\subsubsection{Treinamento Presencial}

Considerando assim o cenário transitório definido pela alta gestão, foram agendados treinamentos presenciais para que fosse explicada a importância da convergência da teoria do processo com a prática da nova atividade operacional a cargo dos colaboradores fiscais, visando atingir níveis melhores de qualidade. A partir de uma decisão do gerente de Finanças da empresa, foi definido que um funcionário em específico da Tesouraria, promovido em janeiro ao cargo de assistente após uma passagem de 6 meses como estagiário, seria o responsável por treinar presencialmente 3 colaboradores da área Fiscal para que os mesmos realizassem os lançamentos das notas fiscais de acordo com o padrão solicitado pela alta gestão.

Durante o mês de abril, foi agendado um treinamento corporativo de 3 horas em que foi revisado todo o processo em questão bem como explicadas as funcionalidades do ambiente financeiro da empresa no sistema ERP da empresa. Nessa apresentação, ficou definido que seria feito um acompanhamento presencial com cada um dos 3 colaboradores do Fiscal a fim de que eles praticassem as novas funcionalidades da ferramenta. Além disso, foram encaminhados materiais e guias práticos teóricos e de consulta para que os novos colaboradores tivessem acesso ao conteúdo explicado oralmente e agora redigido por escrito com passo a passo.

Nesse treinamento presencial pós apresentação oral sobre a teoria, a fim de acompanhar o trabalho e a tela de visão dos funcionários do Fiscal, foi acordado que o colaborador designado da área de Tesouraria definiria uma amostra de 26 exemplos de lançamentos de notas fiscais distribuídos entre os membros da equipe Fiscal durante um intervalo de 10 dias de acompanhamento. Isso, visando o propósito de que eles realizassem as etapas ensinadas para checar se o aprendizado absorvido estava sendo 
corretamente executado com base no guia prático distribuído, já que o propósito era mapear os possíveis erros e dúvidas que pudessem surgir. Os dados deste treinamento estão indicados nas Tabelas 5 e 6.

Tabela 5: Dados Gerais do Treinamento Presencial
\begin{tabular}{|l|l|}
\hline Período & $21 / 04 / 2021$ a 30/04/2021 \\
Amostra & 26 \\
Estagiários & 3 \\
Filiais & 4 \\
Valor Total & $\mathrm{R} \$ 103.225,07$ \\
Valor Médio & $\mathrm{R} \$ 3.970,20$ \\
Com Retenção & $8=30,77 \%$ \\
Sem Retenção & $18=60,23 \%$ \\
Acertos & $24=92,31 \%$ \\
Erros & $2=7,69 \%$ \\
\hline
\end{tabular}

Fonte: Elaborado pelo autor com base em informações calculadas da empresa.

Tabela 6: Dados Detalhados do Treinamento Presencial

\begin{tabular}{|c|c|c|c|c|}
\hline Data & Colaborador & Empresa & Natureza & Valor Bruto \\
\hline $21 / 04 / 2021$ & Estagiário 1 & Radium & Recursos Humanos & R\$ 29.663,34 \\
\hline $21 / 04 / 2021$ & Estagiário 1 & Radium & Informática & $\mathrm{R} \$ \quad 1.240,00$ \\
\hline $21 / 04 / 2021$ & Estagiário 1 & ViaBag & Segurança & 153,00 \\
\hline $21 / 04 / 2021$ & Estagiário 1 & Radium & Segurança & 957,96 \\
\hline $21 / 04 / 2021$ & Estagiário 1 & OnBag & Logística & $\mathrm{R} \$ \quad 7.113,72$ \\
\hline $21 / 04 / 2021$ & Estagiário 1 & OnBag & Logística & $\mathrm{R} \$ \quad 1.770,00$ \\
\hline $21 / 04 / 2021$ & Estagiário 1 & Radium & Construção & $\mathrm{R} \$ 19.020,00$ \\
\hline $28 / 04 / 2021$ & Estagiário 1 & OnBag & Embalagens & R\$ $2.696,75$ \\
\hline $28 / 04 / 2021$ & Estagiário 1 & OnBag & Embalagens & $\mathrm{R} \$ \quad 2.696,75$ \\
\hline $28 / 04 / 2021$ & Estagiário 1 & Radium & gens & $\mathrm{R} \$ 11.250,00$ \\
\hline $28 / 04 / 2021$ & 1 & um & sens & $\mathrm{R} \$ 1$ \\
\hline $22 / 04 / 2021$ & Estagiário 2 & Bag Lojas & Assistência Médica & 550,00 \\
\hline $22 / 04 / 2021$ & Estagiário 2 & Bag Lojas & Consultoria & 300,09 \\
\hline $22 / 04 / 2021$ & Estagiário 2 & Bag Lojas & Assistência Médica & $1.650,00$ \\
\hline $22 / 04 / 2021$ & Estagiário 2 & Bag Lojas & Dedetização & 250,00 \\
\hline $22 / 04 / 2021$ & Estagiário 2 & Bag Lojas & Comunicação Visual & $\mathrm{R} \$ \quad 1.187,00$ \\
\hline $22 / 04 / 2021$ & Estagiário 2 & Bag Lojas & Comunic & $\mathrm{R} \$ 1.187,00$ \\
\hline $22 / 04 / 2021$ & Estagiário 2 & Bag Lojas & Comunicação Visual & $R \$ \quad 1.187,00$ \\
\hline $30 / 04 / 2021$ & Estagiá & Bag Lojas & Logística & $\mathrm{R} \$ \quad 2.071,32$ \\
\hline $30 / 04 / 2021$ & Estagiário 2 & Bag Lojas & Cursos & $\mathrm{R} \$ \quad 1.131,14$ \\
\hline $30 / 04 / 2021$ & Estagiário 2 & Bag Lojas & Construção & 100,00 \\
\hline 27/04/2021 & Estagiário 3 & Bag Lojas & Fotografia & $\mathrm{R} \$ \quad 2.000,00$ \\
\hline $27 / 04 / 2021$ & Estagiário 3 & Bag Lojas & Assistência Médica & 75,00 \\
\hline $27 / 04 / 2021$ & Estagiário 3 & Radium & Assistência Médica & 105,00 \\
\hline $30 / 04 / 2021$ & Estagiário 3 & OnBag & Construção & 120,00 \\
\hline $30 / 04 / 2021$ & Estagiário 3 & Bag Lojas & Limpeza & $\mathrm{R} \$ \quad 3.500,00$ \\
\hline
\end{tabular}

Fonte: Elaborado pelo autor com base em informações calculadas da empresa. 
O mês de abril foi o principal período em que se percebeu uma mudança de postura e de trabalho da área Fiscal no que tange à transição exigida no início do ano pelo novo CEO da empresa. O objetivo principal dessa fase era desenvolver a autonomia dos funcionários do Fiscal a fim de que eles se tornassem mais independentes à medida que esclarecessem dúvidas com a Tesouraria.

Quanto aos dados da Tabela 6, foi observado que em duas situações de acompanhamento presencial ocorreram erros nos lançamentos das notas, caracterizando falhas no reconhecimento das retenções de impostos. Como se tratavam de estagiários, esses dois erros acenderam um alerta sobre o risco que seria para os mesmos realizarem o próprio reconhecimento das retenções de impostos sem a supervisão de um colaborador em cargo superior da área. Por conseguinte, poderia ocorrer de um pagamento via depósito, por exemplo, ser efetuado equivocadamente devido ao lançamento de um valor maior ou menor do que o correto.

\subsubsection{Apresentação do Fluxograma do Processo}

Nessa fase transitória, a primeira medida tomada foi informar a todos os colaboradores da empresa as mudanças que estavam por vir. A fim de centralizar os encaminhamentos dos pedidos, foi criado um novo e-mail colaborativo com participação e inclusão de todos os membros do Fiscal para uma nova caixa de entrada, chamada de Central de Nota. O e-mail do Central de Nota seria um padrão para todos os colaboradores que solicitassem pedidos acompanhados por notas fiscais. Dessa forma, se antes os solicitantes enviavam um e-mail direto para a equipe da Tesouraria, com a modificação o destino dos pedidos seria unicamente ao Central de Nota sem copiar qualquer outra equipe tendo em vista que eles agregariam os lançamentos tanto de valores líquidos quanto de impostos embutidos.

Pela caixa de entrada do Central de Nota, a equipe da área Fiscal nesses primeiros meses dividiu as tarefas com a Tesouraria devido ao pouco treinamento ainda realizado, exclusivamente verbal e com pouca prática baseada em 26 exemplos que representavam uma amostra relativamente pequena comparada com o volume total de lançamentos no intervalo de 10 dias úteis.

As Tabelas 7 e 8 apresentam uma comparação entre os tempos projetados e reais de cada uma das novas etapas descritas. Enquanto o esquema da Figura 2 apresenta a rede de relacionamento do processo de comunicação entre as equipes de Tesouraria e do Fiscal nesses primeiros meses de 2021 durante as fases de testagens. 
Tabela 7: Informações do Fluxograma do Processo Transitório

\begin{tabular}{|c|l|r|}
\hline Etapa & \multicolumn{1}{|c|}{ Agente } & \multicolumn{1}{c|}{ Descrição } \\
\hline $\mathbf{1}$ & Solicitante & Encaminhar e-mail com a nota de serviço para pagamento \\
$\mathbf{2}$ & Estagiário Fiscal & Conferir o e-mail enviado \\
$\mathbf{3}$ & Estagiário Fiscal & Realizar o lançamento da nota \\
$\mathbf{5}$ & Astagiário Fiscal & Encaminhar e-mail à Tesouraria confirmando o lançamento \\
$\mathbf{6 . 1}$ & Assistente Tesouraria & Conferir se o lançamento da nota está correto \\
$\mathbf{6 . 2}$ & Estagiário Fiscal & Solicitar revisão do lançamento da nota \\
$\mathbf{6 . 3}$ & Estagiário Fiscal & Realizar a alteração do lançamento da nota \\
$\mathbf{7}$ & Assistente Tesouraria & Inserir o código de barras/dados para depósito no lançamento \\
$\mathbf{8}$ & Assistente Tesouraria & Encaminhar e-mail ao solicitante confirmando o lançamento \\
9 & CE0 & Aprovar o prosseguimento do pagamento \\
10 & Assistente Tesouraria & Visualizar se o pagamento online foi incluído \\
11.1 & Assistente Tesouraria & Encaminhar o pagamento à parte para inclusão manual \\
11.2 & Analista 2 Tesouraria & Incluir o pagamento manualmente na instituição bancária \\
\hline
\end{tabular}

Fonte: Elaborado pelo autor com base em informações calculadas da empresa.

Tabela 8: Dados do Fluxograma do Processo Transitório: Projetado x Real

\begin{tabular}{|c|l|l|l|}
\hline Etapa & \multicolumn{1}{|c|}{ Agente } & Tempo Projetado (Min:Seg) & Tempo Real (Min:Seg) \\
\hline $\mathbf{1}$ & Solicitante & $01: 30$ & $01: 30$ \\
$\mathbf{3}$ & Estagiário Fiscal & $00: 30$ & $01: 00$ \\
$\mathbf{4}$ & Estagiário Fiscal & $04: 00$ & $05: 00$ \\
$\mathbf{5}$ & Estagiário Fiscal & $00: 30$ & $01: 30$ \\
$\mathbf{6 . 1}$ & Assistente Tesouraria & $00: 30$ & $00: 30$ \\
$\mathbf{6 . 2}$ & Estagiário Fiscal & $02: 00$ & $01: 30$ \\
$\mathbf{6 . 3}$ & Estagiário Fiscal & $00: 30$ & $03: 00$ \\
$\mathbf{7}$ & Assistente Tesouraria & $01: 00$ & $00: 30$ \\
$\mathbf{8}$ & Assistente Tesouraria & $00: 30$ & $01: 00$ \\
$\mathbf{9}$ & CE0 & $02: 00$ & $01: 00$ \\
$\mathbf{1 0}$ & Assistente Tesouraria & $00: 30$ & $02: 00$ \\
$\mathbf{1 1 . 1}$ & Assistente Tesouraria & $01: 00$ & $00: 30$ \\
$\mathbf{1 1 . 2}$ & Analista 2 Tesouraria & $02: 00$ & $01: 00$ \\
\hline \multicolumn{2}{|r|}{ Tempo Total } & 17 minutos e 30 segundos & 22 minutos \\
\hline
\end{tabular}

Fonte: Elaborado pelo autor com base em informações calculadas da empresa. 
Figura 2: Fluxograma do Mapeamento do Processo Transitório

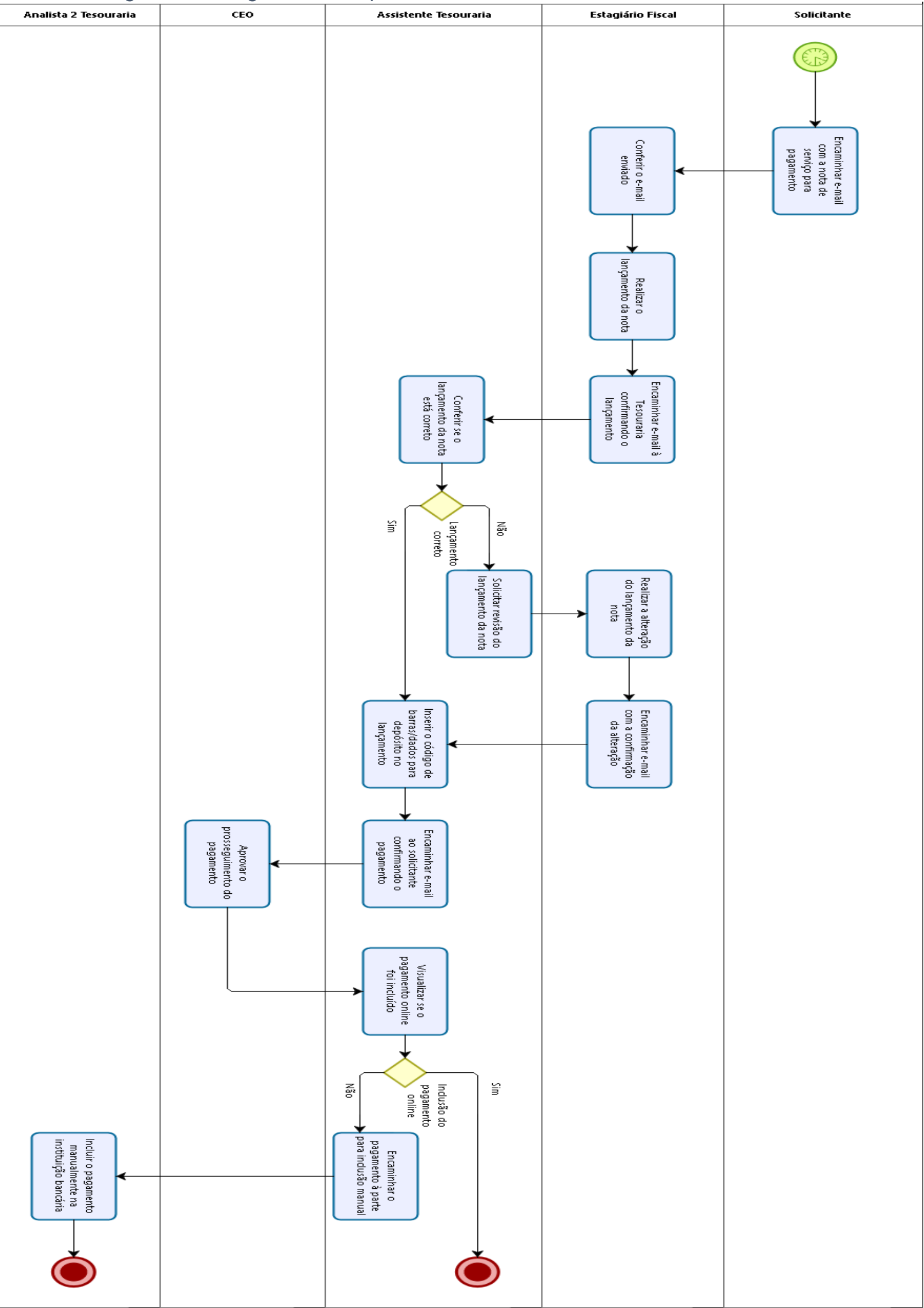




\subsubsection{Diagnóstico do Fluxograma do Processo}

Conforme a Figura 2, foi possível identificar diversas mudanças efetuadas de acordo com a ideia central definida pelo CEO da empresa, com supervisão do gerente financeiro e da coordenadora de Tesouraria.

Diante da entrada da equipe do Fiscal (denominada no endereço de e-mail como Central de Nota) nesse processo, a demanda e a participação dessa área ficaram bem maior do que a empresa terceirizada. Se antes era a equipe da Tesouraria que recebia de imediato os e-mails com notas de serviço solicitando o provisionamento do pedido, agora essa responsabilidade foi direcionada à área Fiscal, que não possui qualquer vínculo primário com o time da Tesouraria. Nesse mesmo processo transitório, houve a eliminação da etapa da verificação das notas fiscais com ou sem retenção, já que o intuito nessa fase de treinamento era que os colaboradores do Fiscal absorvessem todos os tipos de notas de serviço para lançamento sem qualquer distinção.

Tendo em vista o direcionamento inicial ao e-mail corporativo do Central de Nota, percebeu-se que a atuação da Tesouraria estava mais voltada para etapas e funções de fiscalização direta e superior em relação aos colaboradores do Fiscal. Dessa forma, as principais novas atribuições ao assistente principal foram as seguintes: verificar se o lançamento estava correto e solicitar revisões de lançamentos quando fossem encontrados valores divergentes no sistema ERP. Nesse novo processo, é válido comentar que o assistente da Tesouraria correspondia a um ex-estagiário da área que foi efetivado em janeiro de 2021 mas que já participava em 2020 do mesmo processo.

Ademais, foi agregada uma outra novidade relacionada com uma ferramenta na modalidade integrada ao sistema ERP da empresa que, em parceria com a instituição bancária do Itaú, permitiu eliminar a etapa de inclusão manual de informações de pagamento da instituição bancária quando os dados do(a) boleto/nota fiscal fossem inseridos internamente no sistema ERP da empresa. Assim, realizadas as alterações nos lançamentos quando necessárias, na etapa 7 era função da Tesouraria inserir o código de barras ou dados para depósito nos lançamentos realizados com sucesso para provisionamento por inclusão online, sem intermediação da analista para inclusão manual.

De início, a própria Tesouraria era quem selecionava os pagamentos que iriam por inclusão online quando enquadrados nesses segmentos: dados bancários para depósitos e boletos. Isso se explica porque tendo em vista a inexperiência inicial do time do Fiscal com essa funcionalidade da ferramenta, era um alto risco delegar essa responsabilidade à eles. Afinal, corria-se o risco de, por exemplo, pagar por inclusão 
online um valor de $\mathrm{R} \$ 15.430,00$ quando na verdade o pagamento por dados bancários de depósito deveria ser de $R \$ 1.543,00$. Ou seja, um zero a menos ou um zero a mais no valor poderia ter um impacto significativo no caixa da empresa devido a um erro humano. Apesar de passar pelo controle de duas fiscalizações posteriores que poderiam rejeitar esse valor caso a divergência/erro fosse identificado ou acusado por quem registrou esse valor a pagar, a decisão de que essa etapa fosse da Tesouraria permitiu que houvesse uma checagem antecipada antes do envio em definitivo à lista de aprovações do CEO da empresa.

Feito isso, as próximas etapas seguiram conforme a proposta anterior do fluxograma de 2020, em que os pagamentos por inclusão manual da Analista 2 mesmo minimizados continuariam a existir para os casos de erros por inclusão online, embora representasse um percentual pequeno tendo em vista as diversas revisões e checagens antes da lista ser encaminhada ao CEO.

Quanto aos tempos médios das etapas e com base nas fontes de desperdício, é válido destacar os seguintes pontos. De imediato, identificou-se que houve um aumento total aproximado de 4 minutos em relação ao processo inicial do ano de 2020, sem considerar a estimativa de 19 minutos se considerar a etapa da Contabilidade terceirizada. Isso, por sua vez, apesar de representar um aumento elevado e contrário à ideia de redução do lead time dos processos, se justificou por se tratar de um fluxograma de um processo transitório e que ainda estava em análise, ou seja, temporário e que sofreria mudanças conforme novas observações fossem realizadas. A principal ideia elaborada inicialmente pelos superiores da alta gestão era transferir as responsabilidades da empresa de Contabilidade terceirizada para a equipe interna do Fiscal, mesmo com o risco do processo ser lento em algumas etapas, conforme os valores em vermelho da Tabela 8 entre projetado $\mathrm{x}$ real.

Apesar da centralização dos pedidos das notas fiscais na equipe da área Fiscal, é necessário verificar que eles tratavam de novos estagiários agregados à empresa e que ainda não tinham experiência profissional anterior com as atividades. Diante ainda dos casos em que eram solicitadas revisões de lançamentos, o tempo para revisão e relançamento era de 3 minutos tendo em vista que bastava editar alguns dados preenchidos, ao invés de reiniciar. Quanto à ordem de revisão, quem direcionava esse pedido de checagem era o novo assistente da Tesouraria, que com base em sua experiência anterior de 6 meses da empresa, conseguia com sucesso identificar quando uma nota estava errada com base no valor líquido. À essa etapa, identifica-se a fonte 
de desperdício do Retrabalho, devido ao gasto adicional da correção de um lançamento com informações defeituosas e preenchidas equivocadamente pela outra área.

Além dessas etapas de revisão, conforme comentado em parágrafos anteriores, cabia ao assistente a função de inserir o código de barras ou os dados bancários para depósito das notas que eram lançadas pela equipe do Fiscal, visando justamente evitar o envio automático de lançamentos equivocados ao CEO. Assim sendo, considerando que ainda se tratava de um processo transitório, essa nova função que levava cerca de 1 minuto aproximadamente foi uma etapa de Processamento Excessivo ao funcionário da Tesouraria por se tratar de uma atividade que não deveria competir à ele, mas sim a um colaborador da área Fiscal. Por ser uma atividade sob responsabilidade de um colaborador que não era um membro fixo do Fiscal, essa checagem ocupava parte do seu tempo diário que poderia ser alocado para outras funções internas da área da Tesouraria.

Posterior a isso, conforme comentado sobre a introdução de uma nova função de pagamentos por inclusão online no sistema ERP da empresa, uma nova etapa desse processo foi a aprovação a partir de uma pré-lista por parte do CEO antes que os pagamentos fossem inseridos automaticamente no banco. Isso se explica porque cabia ao CEO da companhia analisar os pedidos dos solicitantes, aprovando o que estava a seu conhecimento e rejeitando aquilo que gerasse desconfiança por se tratar de pagamentos duvidosos que não tinham o seu conhecimento inicial quanto ao orçamento, por exemplo. Todavia, esse sistema era consideravelmente rápido por se tratar de um tempo médio para aprovação de 2 minutos, sem a necessidade de avisar ao mesmo sobre a necessidade de aprovação tendo em vista que o CEO cumpria a tarefa diária de visualizar essa planilha especial a fim de não acumular pedidos de aprovação em sua caixa de entrada. Ou seja, evitando ao máximo a fonte de desperdício do Estoque: excesso de pedidos de pagamentos parados na caixa de entrada dele necessitando aprovação.

Ainda sobre os tempos médios comparativos, dessa vez considerando o cenário projetado para $2021 \mathrm{com}$ a realidade da empresa nos primeiros 4 meses desse ano, o aumento do tempo total em aproximadamente 4 minutos e 30 segundos em relação ao cenário projetado se justifica também por outros motivos. Em termos de qualidade, por se tratar de estagiários agregados ao Fiscal, eles não tinham desenvolvido ainda uma habilidade rápida e veloz de adaptação com a ferramenta ERP da empresa. Por esse motivo, a estimativa de tempo para a etapa 3 de lançamento da nota em 4 minutos não foi cumprida, pois essa etapa exigia inicialmente uma atenção especial e redobrada dos 
estagiários a fim de serem evitados erros nos lançamentos. Tanto que a tabela de análise do treinamento presencial sustenta a versão anterior de que os estagiários tinham uma atenção especial para preencher todos os campos do sistema ERP da empresa a fim de que o lançamento fosse executado com sucesso.

Além disso, a etapa 6.1 exigia que o assistente da Tesouraria explicasse formalmente por e-mail quais eram os erros nos lançamentos, já que os estagiários da área Fiscal necessitavam de uma ajuda e orientação quanto ao campo de preenchimento que estava errado. Dessa forma, cabia ao assistente da Tesouraria detalhar quais os campos de preenchimento estavam equivocados assim como, em outros casos, fotografar um print da tela para sinalizar ao Fiscal qual o campo que deveria ocorrer a edição. Além de ser um caso de Retrabalho e de Processamento Excessivo conforme comentado, era uma etapa que demandava tempo do assistente tendo em vista que não era possível apenas solicitar a revisão do lançamento sem indicar o que deveria ser alterado e como ser alterado.

A Figura 3 representa uma demonstração padrão de e-mail encaminhado pelo colaborador da área da Tesouraria cobrando a revisão de um lançamento, com a indicação direta do campo de preenchimento que possui erro no lançamento a fim de facilitar a área Fiscal na alteração do lançamento.

Figura 3: Exemplo de E-mail Solicitando Revisão de Lançamento

ENC: 10/06 - Material de Limpeza Xerém

Gabriel Chermont

Sex, 14/05/2021 15:08

Para: Central De Nota

Cc: PAGAMENTOS

\begin{tabular}{|ll|}
\hline pdf & BOLETO_CLIENTE_28058... \\
& \\
& $99 \mathrm{~KB}$
\end{tabular}

\begin{tabular}{|ll|}
\hline pdf & $3321051673186200012 \ldots \quad V$ \\
\hline ㅁㅁㅁ & $161 \mathrm{~KB}$
\end{tabular}

2 anexos (261 KB) Baixar tudo

Prezados, boa tarde.

Solicito por gentileza a revisão do lançamento.

O código de natureza lançado está como 4120411 (Materiais de Limpeza) que pertence ao antigo plano de contas. O código de natureza correto é 51106009 (Limpeza e Manutenção).

Já retirei o título do Workflow e peço que, quando alterarem, reenviem por Workflow.

Fonte: Outlook - E-mail Corporativo. 


\subsubsection{Oportunidade Diante do Fluxograma do Processo}

Com base nessas observações também verificadas pelo setor Financeiro, a principal questão observada pela equipe se tratou do elevado tempo de registro dos lançamentos das notas por parte dos colaboradores do Fiscal. Apesar do treinamento presencial e dos guias práticos e manuais de instruções, ainda se observava um tempo considerável de lançamento. A hipótese principal para que isso ocorresse foi debatida como sendo o fator da inexperiência como estagiários. Segundo eles, a prática e o tempo seriam os fatores que melhorariam os tempos dos seus processos, ou seja, o sucesso do treinamento teórico dependeria do esforço dos estagiários para abaixar os seus próprios índices ao longo das semanas com mais prática e desenvolvimento.

Uma segunda questão também levantada quanto ao fator do Retrabalho foi de que $o$ assistente da Tesouraria não poderia ser um colaborador fixo da equipe do Fiscal a ponto de sempre fiscalizar e conferir se os lançamentos no sistema estavam certos. Segundo os superiores do setor Financeiro, essa função deveria ser das próprias assistentes e analistas da área Fiscal que também participaram do treinamento oral e explicativo no mês de abril. Somado a esse ponto de diminuição do peso de trabalho para o colaborador da Tesouraria, as novas mudanças também agregariam a necessidade de que a inserção do código de barras e dos dados para depósito partiriam do comando dos próprios colaboradores do Fiscal, pois também era uma função que deveria ser feita simultaneamente ao lançamento, não posteriormente ao lançamento.

Embora fosse identificada uma aproximação muito maior entre Tesouraria e Fiscal, a fase posterior ao processo transitório visava reduzir a responsabilidade da Tesouraria em etapas que passariam a ter o comando e função dos colaboradores do Fiscal. E justamente por causa dessa dependência da área da Tesouraria em verificar o trabalho da equipe Fiscal, o tempo total dessas etapas elevou em aproximadamente 4 minutos por conta dessa fase transitório que urgiu um acompanhamento dependente da Tesouraria.

Analiticamente, diante então da tabela analisada, verificaram-se principalmente três fontes de desperdícios da Manufatura Enxuta: (1) Retrabalho, (2) Processamento Excessivo, (3) Intelectual e (4) Estoque. O primeiro deles se explica pelo fato de a equipe de Tesouraria ter que conferir cada nota lançada pelo Fiscal a fim de verificar se ela efetuara o registro correto no sistema. Já o segundo, pelo fato de a Tesouraria ter que realizar a etapa de inserir o código de barras ou os dados para depósito como direcionamento de pagamentos por inclusão online. Quanto ao desperdício intelectual, apesar da integração participativa do colaborador da Tesouraria na área do Fiscal ser 
benéfica para seu crescimento profissional; essas tarefas de checagem, verificação e validação final tomavam um tempo considerável do assistente da Tesouraria, que acumulava outras demandas em sua área por conta do tempo diário dedicado ao acompanhamento do Fiscal. Embora não se tratasse de uma fonte de desperdício diretamente associada ao processo analisado do lançamento de notas fiscais, essa atenção paralela à área Fiscal prejudicava o desempenho do assistente de Tesouraria já que o mesmo deixava de responder e-mails que acumulavam em sua caixa de entrada, ou seja, ficavam parados e sem respostas, relevante à fonte do Estoque.

Após o apontamento dessas oportunidades e diante da identificação dos gargalos e das fontes de desperdícios, o capítulo seguinte apresenta a ideia que foi projetada pelo setor Financeiro sobre como poderiam ocorrer os novos processos com participação majoritária da área do Fiscal na rede de comunicação, em face da redução máxima das atividades que antes eram realizadas pelos colaboradores da Tesouraria.

\subsection{Fase III: Maio de 2021 - Atual}

No final dessa fase de testes sustentados pelo treinamento presencial e assistencial, foi necessário redesenhar e pensar no melhor processo a ser seguido a partir do mês de maio de 2021 para que a equipe da Tesouraria realizasse o menor número possível de tarefas frente a demanda que antes era maior e mais desgastante para essa do que para o Fiscal em certos aspectos conforme mencionados. O esquema anteriormente apresentado como projetado teve a maioria das suas etapas dentro do padrão de qualidade exigido.

Por isso, após a realização da modelagem de processos com base na ferramenta Bizagi Modeler, se utilizou a técnica da Manufatura Enxuta para observar quais eram as principais fontes de desperdício, etapas limitadoras, gargalos e tarefas que tinham o maior tempo de execução e desperdício e como reduzir ao máximo as etapas de Retrabalho e de Intelectual. A terceira fase dessa mudança geral no processo de notas fiscais corresponde à fase após o mês de maio de 2021, posterior a todos os treinamentos. No próximo capítulo sobre a análise principal do objeto do artigo, o foco temporal da avaliação crítica explorada foi com base no mês de maio e seu processo pós transição até os tempos atuais.

Diante assim de um processo que ainda apresentava inúmeros problemas, gargalos e desperdícios mensurados das duas fases anteriores, verificou-se a oportunidade de otimizar o processo transitório diante de uma participação mais ativa, autônoma e independente do Fiscal como coração fundamental do novo fluxograma, o que foi comentado como a proposta de solução para a situação real observada. 


\section{Análise da Situação e Proposta de Solução}

Posterior aos estudos anteriores que consideraram dois processos recentes aplicados nos últimos 12 meses na empresa em questão no que tange ao lançamento e registro de notas fiscais para pagamento, foi possível traçar um novo fluxograma de processo definitivo a fim de eliminar os gargalos identificados, reduzir o número de etapas e otimizar o tempo médio de processos que antes eram inéditos.

\subsection{Utilização da Ferramenta do Bizagi Modeler}

Diante da análise da situação anterior e mais recente, a primeira questão levantada nesse capítulo trata da importância do uso de uma ferramenta de mapeamento de processos a fim de mensurar os fluxos processuais para visualizar a descrição de cada etapa e os agentes envolvidos nesse meio de comunicação. Assim como no capítulo anterior, a análise do processo descrito nesse capítulo também teve como suporte a ferramenta do Bizagi Modeler a fim de validar as informações de forma conjunta e didática.

No capítulo anterior, foi possível criar e desenvolver estimativas sobre o tempo médio de cada etapa assim como visualizar como um todo o que antes eram partes separadas e incomunicáveis na empresa. Com base assim em uma fundamentação teórica e técnica sustentada pelos princípios da teoria da Manufatura Enxuta, o Bizagi Modeler foi a ferramenta escolhida para também representar nessa fase final 0 fluxograma com a divisão entre agentes e a integração de etapas de forma mais conjunta e única para fins explicativos.

\subsection{Utilização das Técnicas da Manufatura Enxuta}

A partir das informações coletadas quanto aos principais gargalos e fontes de desperdício dos dois processos analisados nas duas fases anteriores, verificou-se que as principais questões levantadas e que necessitariam ser otimizadas ou eliminadas eram as seguintes: (1) Estoque, (2) Processamento Excessivo, (3) Retrabalho e (4) Intelectual.

Sobre o primeiro, sustentou-se que a caixa de entrada dos e-mails dos colaboradores do Fiscal e da Tesouraria não poderia ficar congestionada de mensagens paradas e sem resposta, já que a demanda de pedidos exigia que os colaboradores ficassem atentos aos prazos de vencimento das notas fiscais e pedidos de resposta.

Quanto ao Processamento Excessivo, concordou-se que a equipe de Tesouraria não deveria ser uma peça fixa no coração do time do Fiscal tendo em vista que essa 
última deveria desenvolver sua própria autonomia e dependência de trabalho com regras internamente estabelecidas pelos colaboradores.

Sobre o aspecto do Retrabalho; a checagem, a verificação e a correção dos lançamentos defeituosos dos funcionários do Fiscal deveriam ficar também sob a responsabilidade interna do Fiscal, a fim de não sobrecarregar o time da Tesouraria com essa função de controle corretivo após o lançamento.

E quanto à fonte do nível Intelectual, justamente com a eliminação do peso maior na equipe da Tesouraria, os membros do Fiscal utilizariam seus conhecimentos e habilidades em funções definitivas da área em que atuam diretamente, a fim de que justamente as capacidades intelectuais da equipe do Fiscal fossem aproveitadas devidamente em substituição à Tesouraria.

Sobre os princípios que devem ser seguidos pelas organizações conforme apontado por Jones e Womack (1998) a fim de que o sistema da implementação das técnicas da Manufatura Enxuta seja completo em vários sentidos, o novo fluxograma de processos sugerido para o mês de maio em diante se baseou nos cinco aspectos elencados cronologicamente pelos autores: Valor, Fluxo de Valor, Fluxo Contínuo, Produção Puxada e Perfeição.

Para o primeiro deles, Valor, como o cliente final não é o consumidor de um produto a ser comercializado, mas sim o solicitante do pedido de pagamento que possui uma nota fiscal, será ele quem definirá se o valor entregue correspondeu às suas necessidades, essas que se relacionam com o pagamento dentro do prazo e de acordo com o valor correto para evitar renegociações ou acertos.

O segundo aspecto, o Fluxo de Valor, se refere ao processamento de todas as etapas que envolvem os materiais (e-mails), as informações (instruções no e-mail e detalhes da nota fiscal) e as pessoas (colaboradores e agentes).

O terceiro, o Fluxo Contínuo, está relacionado com o rápido processamento interno para responder aos e-mails com agilidade e sem deixar o solicitante em espera ou com incerteza por tanto tempo sem alguma resposta sobre o provisionamento e previsão de pagamento.

Quanto ao quarto ponto, da Produção Puxada, ela é justificada pelo fato de que os registros de pagamentos acompanhados de nota fiscal não permitem uma antecipação dos lançamentos nem previsibilidade de futuros pagamentos sem que a nota fiscal seja impressa ou registrada internamente por e-mail. Assim, as únicas 
previsões de pagamentos que são realizadas no sistema ERP dependem do comando do próprio solicitante quando forem casos de pagamentos parcelados, por exemplo.

E, finalmente, sobre a Perfeição, o quinto aspecto, explicado pela proposta principal de reduzir os desperdícios, otimizar os processos e criar uma rotina cada vez mais amadurecida e padronizada em níveis de qualidade no Fiscal a fim de evitar erros de lançamentos e pagamentos de valores equivocados diante de falhas humanas dos colaboradores. A partir de acertos consecutivos no registro de lançamentos, os solicitantes de pedidos atribuirão uma maior confiança ao time do Fiscal, diante de um padrão de lançamentos corretos e que correspondem à necessidade de pagar um pedido dentro do prazo e com base no valor indicado.

Por esse motivo, após relembrar as principais fontes de desperdício atreladas aos dois processos descritos no capítulo anterior assim como os aspectos destacados por Jones e Womack (1998), foi possível programar e desenvolver um novo fluxograma para o processo em questão após todas as observações e mudanças sugeridas.

\subsection{Apresentação do Fluxograma do Processo}

Diante então de todas os cenários projetados e a partir de todas as análises com base nos processos em projeção e em real, foi possível definir um novo fluxograma de processo final em definitivo para ser testado pela empresa após todas as verificações apresentadas. A Figura 4 a as Tabelas 9 e 10 apresentam as descrições das etapas bem como o tempo médio de cada uma delas, considerando o cenário estimado e projetado frente aos valores reais já observados no mês de maio de 2021.

Tabela 9: Informações do Fluxograma do Processo Final

\begin{tabular}{|c|l|r|}
\hline Etapa & \multicolumn{1}{|c|}{ Agente } & \multicolumn{1}{c|}{ Descrição } \\
\hline 1 & Solicitante & Encaminhar e-mail com a nota de serviço para pagamento \\
2 & Analista Fiscal & Conferir o e-mail enviado \\
3 & Analista Fiscal & Encaminhar e-mail com as informações do lançamento \\
$\mathbf{4}$ & Estagiário Fiscal & Realizar o lançamento da nota \\
$\mathbf{5}$ & Estagiário Fiscal & Inserir o código de barras/dados para depósito no lançamento \\
$\mathbf{6}$ & Estagiário Fiscal & Encaminhar e-mail à Tesouraria e ao solicitante confirmando o lançamento \\
$\mathbf{7}$ & CE0 & Aprovar o prosseguimento do pagamento \\
$\mathbf{8}$ & Assistente Tesouraria & Visualizar se o pagamento online foi incluído \\
9.1 & Assistente Tesouraria & Encaminhar o pagamento à parte para inclusão manual \\
9.2 & Analista 2 Tesouraria & Incluir o pagamento manualmente na instituição bancária \\
\hline
\end{tabular}

Fonte: Elaborado pelo autor com base em informações calculadas da empresa. 
Tabela 10: Dados do Fluxograma do Processo Final: Projetado x Real

\begin{tabular}{|c|c|c|c|}
\hline Etapa & Agente & Tempo Projetado (Min:Seg) & Tempo Real (Min:Seg) \\
\hline 1 & Solicitante & $01: 30$ & $01: 30$ \\
\hline 2 & Analista Fiscal & $00: 30$ & $01: 00$ \\
\hline 3 & Analista Fiscal & $00: 30$ & 01:00 \\
\hline 4 & Estagiário Fiscal & 04:00 & 04:00 \\
\hline 5 & Estagiário Fiscal & 01:00 & 01:00 \\
\hline 6 & Estagiário Fiscal & 01:00 & $01: 30$ \\
\hline 7 & CEO & 02:00 & 02:00 \\
\hline 8 & Assistente Tesouraria & $00: 30$ & $00: 30$ \\
\hline 9.1 & Assistente Tesouraria & 01:00 & $01: 00$ \\
\hline 9.2 & Analista 2 Tesouraria & 02:00 & 02:00 \\
\hline & Tempo Total & 14 minutos & 15 minutos e 30 segundos \\
\hline
\end{tabular}

Fonte: Elaborado pelo autor com base em informações calculadas da empresa.

Figura 4: Fluxograma do Mapeamento do Processo Final

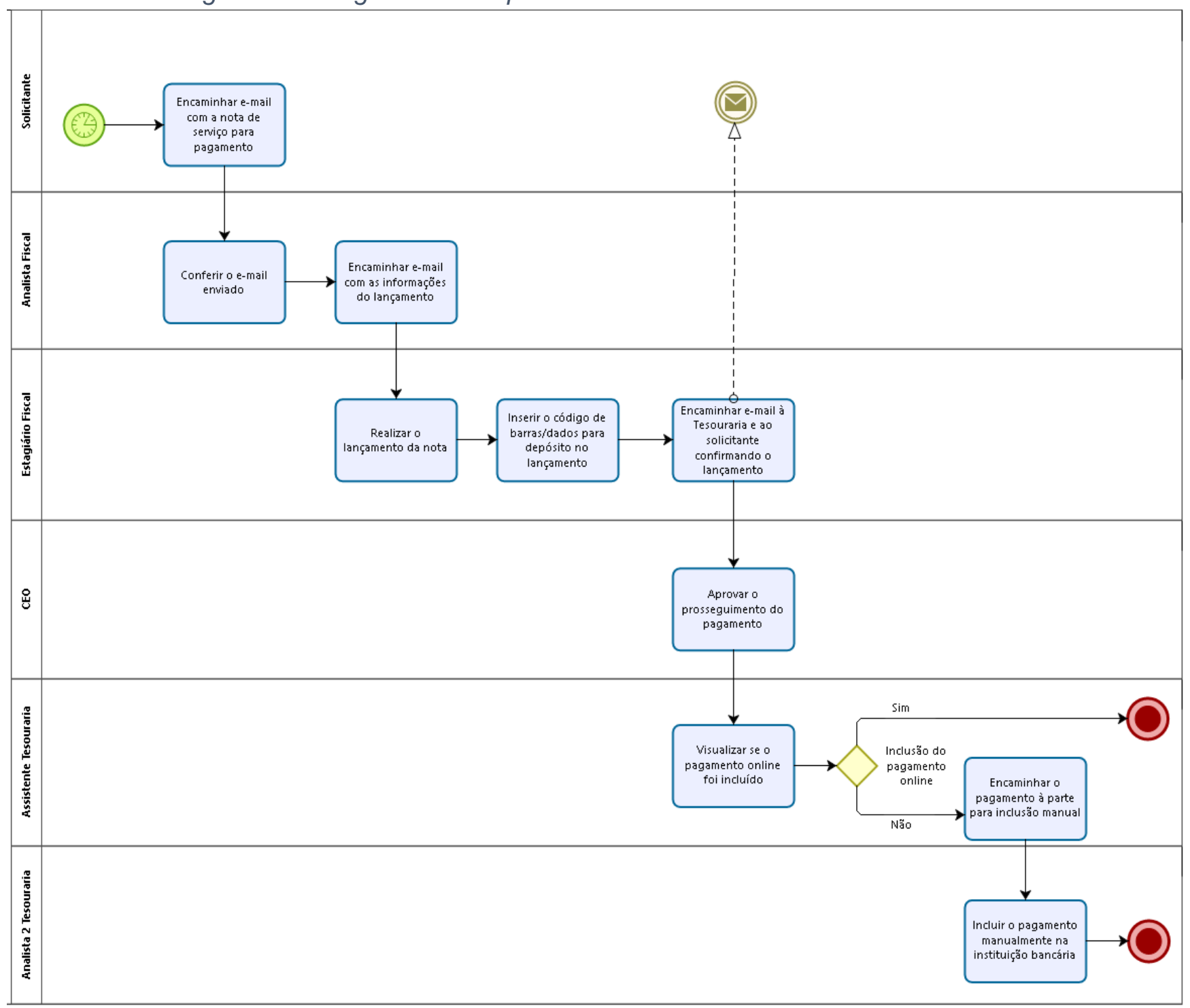

Fonte: Elaborado pelo autor com base em informações calculadas da empresa. 


\subsection{Diagnóstico do Fluxograma do Processo}

Após analisar as Tabelas 9 e 10, foi possível extrair observações a respeito dos dados apresentados nos cenários projetado e real. Considerando o tempo total de todos os eventos, o cenário atual da empresa ainda não está de acordo com os objetivos, já que embora apresentando tempos menores, ainda assim algumas etapas ultrapassam os tempos esperados.

No caso do processo geral, percebe-se uma diminuição do emprego das funções a cargo da equipe de Tesouraria, já que essa só está acionada no processo em caso de erro do pagamento por inclusão online. Anterior às últimas etapas, o restante do processo, seu início e meio, estão sob responsabilidade do time do Fiscal, sem mais qualquer processo de conferência ou de fiscalização direta por parte de algum colaborador da Tesouraria.

Entre as novidades apresentadas, percebeu-se que a analista fiscal participa do início do processo ao conferir os e-mails enviados antes de encaminhar os lançamentos das notas fiscais para os estagiários. Relembrando a fase de treinamento presencial, de uma amostra de 26 exemplos, 2 deles apresentaram erro por falha intelectual da interpretação técnica do colaborador na identificação das retenções de impostos dos lançamentos. Visando a otimização nos casos e considerando que a analista fiscal possui mais experiência profissional e cargo superior aos estagiários da área, foi ordenado que ela teria a função de antecipar ao estagiário informações sobre o lançamento. Dessa forma, o comando partiria da analista, e o risco de lançamento equivocado por desconsiderar a retenção de impostos seria mínimo, devido ao conhecimento avançado da analista.

Além dessa etapa, percebeu-se também que o próprio estagiário do Fiscal fica responsável por encaminhar em um único e-mail o aviso do lançamento, seja para a equipe da Tesouraria seja para o solicitante inicial. Dessa forma, o trabalho de confirmar o provisionamento do pagamento que antes era do assistente de Tesouraria agora, com as mudanças, passa a ser do próprio Fiscal, que dispara um único e-mail para dois destinatários diferentes com a mesma informação embutida e sem Retrabalhos ou Processamento Excessivo. 


\section{Conclusões e Contribuições do Estudo}

Por fim, em um raciocínio geral sobre o processo final, foram obtidas as seguintes conclusões finais sobre o processo. Apesar de o tempo total médio ainda não ser equivalente à projeção definida como meta, as áreas e os agentes do processo estão no caminho correto para cumprir, pois a prática e o aprendizado constante após a fase de testes permitirão que os agentes reduzam os tempos de envios de e-mail, bem como desenvolvam novas ferramentas e práticas de trabalho que agilizem ainda mais suas atividades diárias.

Quanto às fontes de desperdício, verifica-se um aproveitamento intelectual positivo da analista fiscal nas etapas de conferência, que antes era da equipe de Tesouraria que não pertencia ao time do Fiscal. A partir desse aproveitamento, existe uma integração maior entre os funcionários da área Fiscal, já que a participação ativa dessa analista que antes não estava engajada no processo facilita a visualização e o repasse de informações corretas aos estagiários, evitando assim desperdícios com revisões e correções de lançamentos com base em interpretações equivocadas. Essas revisões ocupavam parte dos e-mails da caixa de entrada da Tesouraria, pois os funcionários tinham que verificar e-mail por e-mail para checar se o lançamento da nota fiscal no sistema estava correto. Assim, evita-se outra fonte de desperdício, o Estoque de e-mails parados na caixa de entrada e que poderiam travar o processamento e 0 provisionamento de pagamentos dentro do prazo de vencimento.

Quanto à outra fonte de desperdício, verifica-se também o fim das etapas de Retrabalho por parte da Tesouraria, já que elas foram separadas do processo pois não é mais necessário realizar um acompanhamento paralelo sobre a procedência correta ou incorreta dos lançamentos de notas fiscais. Nesse sentido, a parceria com o time da Tesouraria no novo processo foi reduzida positivamente devido ao avanço dos estagiários que reduziram suas taxas de erros, que agora são acompanhados por colaboradores do mesmo time.

No que tange também à fonte do Processamento Excessivo, percebe-se que a eliminação das etapas de checagem e conferência da área da Tesouraria permite que os funcionários desta área se concentrem em outros processos e atividades internas do seu próprio espaço de atuação, já que não tem mais as operações de ajuda paralela e que eram indiferentes para a Tesouraria por se tratar de uma fiscalização direta com outra área da empresa. Aquela que, a partir das mudanças, estimula indiretamente o desenvolvimento da autonomia e da independência do Fiscal para guiar internamente o 
processo entre os membros da própria área sem depender diretamente das correções diretas da Tesouraria.

Além disso, percebe-se também o quão imprescindível é estudar e aplicar nas empresas e nos ambientes de trabalhos as técnicas da Manufatura Enxuta visando o mapeamento de processos com base na identificação de gargalos, eliminação das fontes de desperdícios, redução do tempo médio de etapas e otimização da comunicação.

Quanto ao caso prático, da empresa do segmento de varejo em artefatos de couro e artigos de viagem, foi possível identificar ao longo do tempo como as teorias da Manufatura Enxuta contribuíram para que o setor Financeiro da companhia alcançasse um processo final que permitisse a otimização das etapas visando contribuir para a entrega de valor ao cliente, que nesse caso era o solicitante inicial dos pagamentos. Embora a técnica da Manufatura Enxuta na maioria dos artigos acadêmicos seja utilizada para fins de análise de produção de bens materiais em fábricas e esteiras de montagem, o presente artigo se construiu em um exemplo do benefício da aplicação dessas técnicas em áreas internas de ambientes empresariais e escritórios, de maneira positiva e agregadora para analisar processos internos em empresas, como por exemplo nas trocas de e-mails que foram bases do estudo.

O presente artigo, além de representar um caso prático de análise de um processo interno no ambiente de escritório de uma empresa, foi uma demonstração de como outros setores além do Financeiro também podem aplicar essas técnicas em suas rotinas, pois a conceituação teórica sobre as fontes de desperdício da Manufatura Enxuta facilita o processo de identificação dos gargalos mesmo para aqueles que estão iniciando e tendo um primeiro contato com as técnicas de mapeamento de processos.

Ademais, conclui-se também que, considerando que o artigo se baseou em 1 lote de pagamento como sendo de 1 nota fiscal para cálculo médio do tempo de cada etapa, os valores e números observados devem ser multiplicados pelo lote diário de trabalho que os colaboradores têm na empresa, o que sustenta que a redução de tempo em minutos é significante considerando a demanda por dia que a área recebe de aproximadamente 15 solicitantes.

A respeito de sugestões e contribuições para o ramo da Administração, o autor pondera que é válido que mais empresas utilizem essas técnicas de mapeamentos de processos em seus ambientes internos, pois os próprios funcionários são recursos humanos e valiosos que podem ter suas tarefas otimizadas ao serem treinados para desempenhar um papel melhor e mais eficiente em suas rotinas diárias. 
Além disso, antes do início desse trabalho, verificou-se que são raras as referências de pesquisa em artigos acadêmicos que trouxeram uma análise de um processo interno em escritório empresarial. A maioria dos materiais coletados tratava de exemplos práticos que consideravam lotes de produção de bens materiais em fábricas, diferente do ambiente em estudo. Por esse motivo, registra-se também a necessidade de um estímulo para que professores apliquem mais exemplos práticos de estudos de caso sobre esse tema em sala de aula, a fim de que os próprios alunos possam trazer esses materiais inéditos para o interior das empresas em que estagiam ou que trabalham.

Assim, é válido que as empresas atuais, visando se destacar em termos de competitividade no mercado com base nos princípios como os do programa Brasil Mais, utilizem os recursos da Manufatura Enxuta em seus processos internos a fim de analisar e revisar suas operações administrativas mesmo que não relacionadas diretamente com a entrega de um produto ou serviço final ao consumidor, mas com atividades administrativas em nível de ambientes de trabalho em escritório.

Finalmente, denota-se a contribuição dessas análises para o aperfeiçoamento e revisão de processos internos em empresas, bem como o incentivo de sua aplicabilidade em diversos setores e departamentos nem que sejam em atividades básicas do dia a dia de trabalho, uma vez que os resultados agregados influenciam positivamente em uma maior entrega de valor ao cliente quando o colaborador se identifica como recurso humano e valioso em uma empresa, atuando como um agente produtor e gerador de valor final ao cliente. 


\section{Referências Bibliográficas}

ALMEIDA, Vinicius Nóbile de. O que é BPM (Business Process Management): o guia para implantar a Gestão de Processos na sua empresa. Euax. Disponível: < https://www.euax.com.br/2015/06/bpm-business-process-management-o-que-e/ >. Acesso em: 29 de março de 2021.

ALMEIDA, Vinicius Nóbile de. O que é BPMN (Business Process Model and Notation) e como aplicar essa notação na Modelagem de Processos. Euax. Disponível em: < https://www.euax.com.br/2017/02/o-que-e-bpmn-business-process-model-andnotation/ >. Acesso em: 29 de março de 2021.

ALMEIDA, Vinicius Nóbile de. O que é Gerenciamento de Processos de Negócio: entenda como os processos podem afetar a sua organização. Euax. Disponível em: <https://www.euax.com.br/2018/09/gerenciamento-de-processos-de-negocio/>. Acesso em: 29 de março de 2021.

ALVAREZ, R. R.; ANTUNES Jr., J. A. V. Takt time: contexto e contextualização dentro do Sistema de Produção. Revista Gestão \& Produção, v. 8, n. 1, p. 01-18, abr. 2001.

ARAÚJO, L.C. TORRES, A.G. MARTINES, S.S. Gestão de processos: melhores resultados e excelência organizacional. 1 ed. Atlas, 2011.

ARAUJO, Luis César G. de. Organização, sistemas e métodos: e as tecnologias de gestão organizacional, benchmarking, empowerment, gestão pela qualidade total, reengenharia. 5. Ed. São Paulo: Atlas, 2011.

BALARDIM, Eduardo. Lean Manufacturing: O que é, Objetivos e Princípios. 2019. Disponível em: < https://fia.com.br/blog/lean-manufacturing/ >. Acesso em: 31 de março de 2021.

Brasil Mais. Quer melhorar a gestão e a produtividade da sua empresa?. Disponível em: < https://brasilmais.economia.gov.br/ >. Acesso em: 23 de abril de 2021.

CAMPOS, V.F. Gerenciamento da rotina do trabalho do dia a dia. Nova Lima: ING Tecnologia e Serviços Ltda, 2004.

CAMPOS, V.F. TQC - Controle de Qualidade Total (no estilo Japonês). Nova Lima: INDG Tecnologia e Serviços LTDA. Nova Lima, 2004.

Casa Civil, Presidência da República, Legislação, LEI № 11.788, DE 25 DE SETEMBRO DE 2008. Disponível em: < http://www.planalto.gov.br/ccivil_03/_ato20072010/2008/lei/l11788.htm >. Acesso em: 08 de outubro de 2020.

CHIAVENATO, Idalberto. Gestão de Pessoas: o novo papel dos recursos humanos nas organizações. 3.ed.; Rio de Janeiro: Elsevier, 2008.

CHIAVENATO, Idalberto. Introdução à teoria geral da Administração. 9a edição. Barueri, SP. Manole, 2014. 
CHIAVENATO, Idalberto. Recursos Humanos: 0 Capital Humano das Organizações. São Paulo: Editora Atlas, 2004, p. 17-18.

D’ASCENÇÃO, L.C.M. Organização, Sistemas e Métodos: análise, redesenho e informatização de processos administrativos. São Paulo: Atlas, 2001.

DEBRUIN, T.; DOEBELI, G. BPM as an organisational approach: the experience of an Australian transport provider. In: ROSEMANN, M.; VON BROCKE, J. (Ed.). Handbook on Business Process Management. Berlin: Springer, 2009. v. 1.

FINGAR, Peter. "Extreme Competition: Innovation And The Great 21st Century Business Reformation". Editora Meghan-Kiffer Press, 2006.

GOMES, F. M.M.; FAUSTINO, G.G.; TONANI, M.; PORCINCULA, S.; SOMERA, S.C.; BEICKER, W.; PAZIN-FILHO, A. Mapeamento do fluxo de trabalho: Engenharia Clínica do HCFMRP-USP. Revista de Medicina USP, v. 48, n.1, 41-47, 2015.

GONÇALVES, J. E. L. As empresas são grandes coleções de processos. RAE Revista de Administração de Empresas, São Paulo, jan./mar. 2000.

GONÇALVES, J. E. L. Os novos desafios da empresa do futuro. RAE - Revista de Administração de Empresas, São Paulo, jul./set. 1997.

GONÇALVES, J.E.L. Processo, que processo? Revista de Administração de Empresas, v. 40, n. 4, p. 8-19, 2000.

JONES, D., WOMACK, J. 1998, A Mentalidade Enxuta nas Empresas. Editora Campus.

KIPPER, L.M.; ELLWANGER, M. C.; JACOBS, G.; NARA, E. O. B.; FROZZAS, R. 2011. Gestão por processos: Comparação e análise entre metodologias para implantação da gestão orientada a processos e seus principais conceitos. Revista Tecno-Lógica, v. 15, n. 2, p. 89-99, 2011.

KOTLER, P.; KELLER, K. Administração de Marketing 15ª ed; São Paulo: Pearson, 2019.

LIMA, Davi de. Bizagi Modeler: modele processos de negócio. Tech Tudo. Disponível em: < https://www.techtudo.com.br/tudo-sobre/bizagi-modeler.html >. Acesso em: 29 de março de 2021.

LUCINDA, Marco Antônio. Qualidade: fundamentos e práticas para cursos de graduação. Rio de Janeiro: Brasport, 2010.

MARETH, T.; ALVES, T. W.; BORBA, G. S. Mapeamento de processos e simulação como procedimentos de apoio à gestão de custos: uma aplicação para o processo de registros e matrículas da universidade de cruz alta. In: IX CONGRESSO USP, 2003. Anais... São Paulo, 2009. 
MIYASHITA, P.T.; SALOMON, V.A.P. Mapeamento de processos em empresa prestadora de serviços de seguros. In: ENCONTRO NACIONAL DE ENGENHARIA DE PRODUÇÃO, 2011. Anais... Belo Horizonte: ABEPRO, 2011.

OHNO, Taiichi. O Sistema Toyota de Produção - Além da Produção em Larga Escala. Editora Bookman, 1997.

OLIVEIRA, D.P.R. Administração de processos: conceitos, metodologia, práticas. 2. ed. São Paulo: Atlas, 2007.

OLIVEIRA, Hilderline Câmara de; SANTOS, Joseneide Sousa Pessoa dos; CRUZ, Eduardo Franco Correia. O Mundo do Trabalho: concepções e historicidade. III Jornada Internacional de Políticas Públicas. São Luiz do Maranhão, 2007.

PAIM, R. et al. Gestão de Processos: Pensar, Agir e Aprender. Editora Bookman, 2009.

Plataforma Bizagi Modeler. Bizagi Modeler: modelagem de processo potente e intuitiva. Disponível em: < https://www.bizagi.com/pt/plataforma/modeler >. Acesso em: 29 de março de 2021.

SLACK, N. Gerenciamento de Operações e de Processos - princípios e práticas de impacto estratégico. 2.ed.; Porto Alegre: Bookman, 2013.

SMITH, H.; FINGAR, P. Business process management: the third wave. MeghanKiffer Press, 2003.

SOBRAL, Filipe. PECl, Alketa. Administração: teoria e prática no contexto brasileiro. São Paulo: Person Prentice Hall, 2008.

SOBRAL, Filipe. PECl, Alketa. Administração: teoria e prática no contexto brasileiro. $2^{\mathrm{a}}$ edição. São Paulo: Person Education do Brasil, 2013.

TAYLOR, Frederick Winslow. Princípios de administração científica. 8. ㄹ ed. São Paulo: Atlas, 1990.

VALLE, R. OLIVEIRA, S.B. Análise e modelagem de processos de negócio: foco na notação BPMN (Business Process Modeling Notation). São Paulo: Atlas, 2013.

WOMACK, J. P.; JONES, D. T.; ROOS, D. A máquina que mudou o mundo. 14. ed. Rio de Janeiro: Campus, 1992. 